\title{
DEEP-WATER SEDIMENT BYPASS
}

\author{
CHRISTOPHER J. STEVENSON, ${ }^{1}$ CHRISTOPHER A.-L. JACKSON,${ }^{2}$ DAVID M. HODGSON,${ }^{1}$ STEPHEN M. HUBBARD, ${ }^{3}$ AND \\ JORIS T. EGGENHUISEN ${ }^{4}$ \\ ${ }^{1}$ School of Earth and Environment, University of Leeds, Leeds LS2 9JT, U.K. \\ ${ }^{2}$ Basins Research Group (BRG), Department of Earth Sciences and Engineering, Imperial College, London SW7 2AZ, U.K. \\ ${ }^{3}$ Department of Geoscience, University of Calgary, Calgary T2N 1N4, Canada \\ ${ }^{4}$ Department of Earth Sciences, Utrecht University, Utrecht 3584 CD, The Netherlands \\ e-mail: C.J.Stevenson@leeds.ac.uk
}

\begin{abstract}
Submarine gravity flows are a key process for transporting large volumes of sediment from the continents to the deep sea. The location, volume, and character of the sediment bypassed by these flows dictates the areal extent and thickness of the associated deposits. Despite its importance, sediment bypass is poorly understood in terms of flow processes and the associated stratigraphic expression. We first examine the relationships between the physical parameters that govern bypass in flows, before assessing the variable stratigraphic expression of bypass from modern seafloor, outcrop, and subsurface datasets. Theoretical and numerical approaches distinguish grain size, slope, flow size, and sediment concentration as parameters that exert major controls on flow bypass. From field data, a suite of criteria are established to recognize bypass in the geological record. We identify four bypass-dominated zones, each of which is associated with a set of diagnostic criteria: slope-channel bypass, slope-bypass from mass wasting events, base-of-slope bypass, and basin-floor bypass. As the expression of bypass varies spatially and is dependent on the scale of observation, a range of scale-dependent criteria are required for robust interpretation of these zones in the field or subsurface. This synthesis of deep-water sediment bypass highlights the challenge in quantitatively linking process with product. The establishment of criteria to recognize sediment bypass, qualitatively linked with flow processes, is an important step towards improving our understanding of submarine flow dynamics and resultant stratigraphic architecture.
\end{abstract}

\section{INTRODUCTION}

Submarine sediment density flows (herein referred to as submarine flows) comprise a range of processes from dilute turbidity currents to cohesive debris flows (Bouma 1962; Lowe 1982; Mulder and Alexander 2001; Meiburg and Kneller 2010; Talling et al. 2012). They are the principal mechanism for transporting and bypassing large volumes of sediment from the continents to the deep ocean. Sediment bypass concerns the transport of sediment by a flow beyond a fixed area or geographical point. The bypassed sediment, which may include substrate material entrained during the passage of the flow, is subsequently deposited farther down-system. The deposits of submarine flows, turbidites, debrites, and hybrid beds are relatively thin (decimeters to meters) and can be areally extensive $\left(100 \mathrm{~s} \mathrm{~km}^{2}\right)$. Thus, flows must inherently bypass a significant proportion of their sediment load downsystem of a fixed geographical location along the flow pathway. This is a fundamental principle behind deep-water facies tract models, which predict sequential deposition of particular facies and bed thicknesses along a flow pathway (Bouma 1962; Lowe 1982; Mutti 1992; Sumner et al. 2012) (Fig. 1A). For example, a hypothetical flow depositing a 1 -m-thick bed along a $10 \mathrm{~km} 2 \mathrm{D}$ tract deposits only 0.0001 fraction of its initial sediment load every meter, and bypasses orders of magnitude more sediment at all but its most distal locations. The amount of sediment bypassed is dictated by the longitudinal (Fig. 1B) and vertical (Fig. 1C) structure of a flow, which evolves with distance along the flow pathway
(Fig. 1A, B; Points X, Y, and Z). Paola and Martin (2012) have formalized this principle at the system scale by applying mass-balance calculations to ponded deep-water successions, described from seismic datasets, to estimate the proportion of deposition versus bypass at particular locations along the sediment pathway.

Underfilled modern submarine channels with morphologically related submarine fans demonstrate that significant volumes of sediment are bypassed down the continental slope. Amalgamated coarse sands and gravels dominate the channel thalwegs and fine-grained internal levee and terrace deposits occur over their banks (e.g., Paull et al. 2005; Babonneau et al. 2010). Similar facies are found within the axes of ancient channel-fill successions, interpreted to represent the depositional record of large volumes of sediment bypassed into deeper water (e.g., Winn and Dott 1977; Mutti and Normark 1987; Pickering et al. 2001; Hodgson et al. 2011; Hubbard et al. 2014). In addition, fine-grained thin-bedded channel-base drapes found in ancient channel fills have been interpreted to represent high-energy, largely bypassing flows that only deposited material from their tails (Mutti and Normark 1987; Macauley and Hubbard 2013). Farther down the slope profile at the base of slope, channel-lobe transition zones (CLTZs) have been shown to be bypassdominated areas in modern systems (Normark 1978; Normark et al. 1979; Wynn et al. 2002a) and ancient systems (Mutti and Normark 1987; Ito et al. 2014; van der Merwe et al. 2014). CLTZs are characterized by a range of scour types draped by fine-grained sandstones and mudstones 


\section{A) Idealized Facies Tract Models}

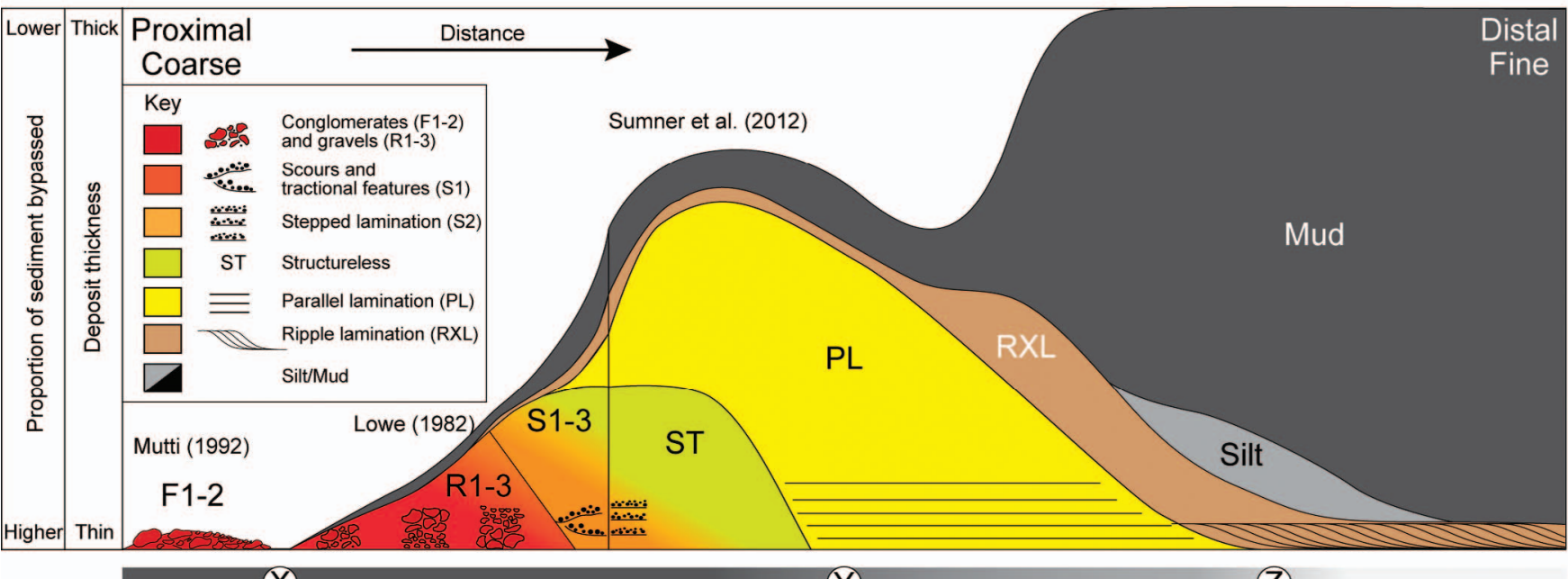

(B) Longitudinal Flow Structure

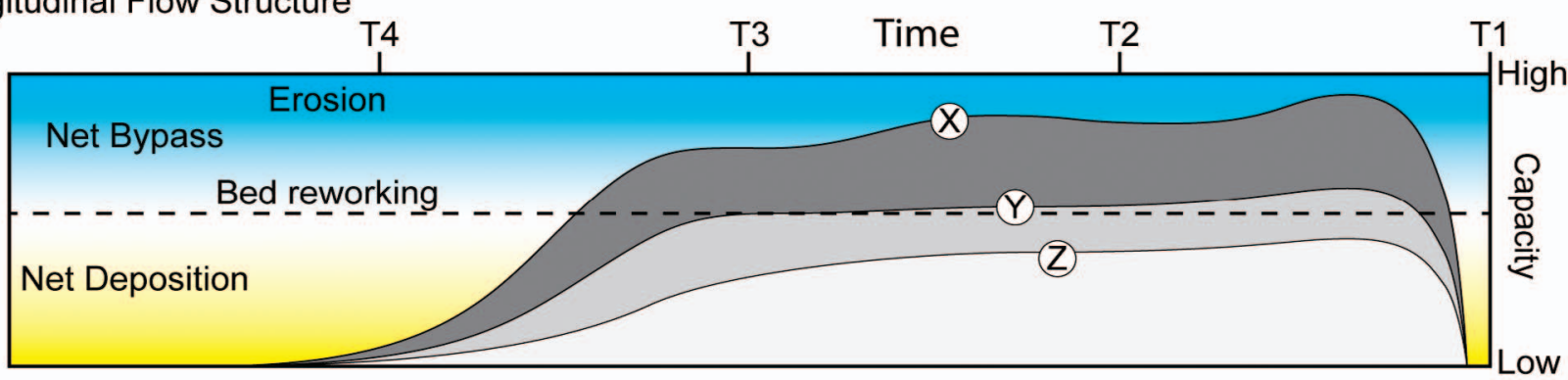

\section{C) Vertical Flow Structure}

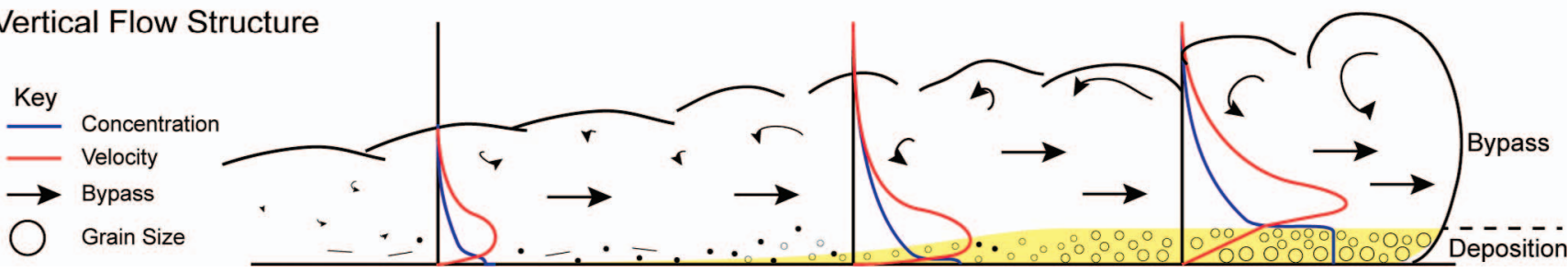

FIG. 1.-A) A compilation of a number of idealized bed-scale facies tracts moving down-system from conglomerates (F1-2; adapted from Mutti 1992), gravels, and coarse-grained sands overlain by a fine-grained drape (S1-3; adapted from Lowe 1982), to finer-grained structured sands and muds (modified from Sumner et al. 2012). Note that bypass is inversely proportional to deposit thickness. B) Periods of deposition, bypass, then deposition over a fixed geographical point produced from variations in the longitudinal structure of the flow (adapted from Kane et al. 2009b). X, Y, and Z show how this structure varies in a number of fixed positions down the system (linked with Part A). C) Deposition from the basal layer can occur whilst sediment in the upper parts of the flow is bypassed down-system.

and laterally discontinuous cross-laminated sandstone beds (Cazzola et al. 1981; Mutti and Normark 1987; Chapin et al. 1994; Palanques et al. 1995; Morris et al. 1998; Wynn et al. 2002a; Gardner et al. 2003; MacDonald et al. 2011; Ito et al. 2014). Deposits of dune-scale crosslaminated sandstones have been interpreted to record sediment bypass in basin-floor settings (Amy et al. 2000). The presence of sharp grain-size breaks in individual beds has also been considered as an indicator of sediment bypass (Gladstone and Sparks 2002; Kneller and McCaffrey 2003).

Identification and examination of sediment bypass zones provide insights into the dynamics of submarine flows (Fig. 1), which improves our understanding of a key process by which sediment is moved across the planet. The timing and location of sediment bypass is important in deep-water systems because this process ultimately dictates the extent and thickness of the associated deposits (Fig. 1). Hence, from an applied perspective, recognizing the degree and caliber of sediment bypassed through any particular region is important for the down-system prediction of sandstone bodies in hydrocarbon plays and may also aid geohazard assessments for seafloor infrastructure. Despite many studies that describe or interpret areas of deep-water sediment bypass, the phenomenon, and recognition criteria, have not been systematically described. Here, we bring together theoretical and numerical approaches that mathematically describe the processes that govern bypass. We then synthesize the expression of bypass in the geological record from modern seafloor, outcrop, core, and subsurface datasets. Examining these different types of field data allows the stratigraphic and planform expression of bypass to be described and interpreted across a broad range of scales (centimeters to 100s km; Fig. 2). From these data we address the 


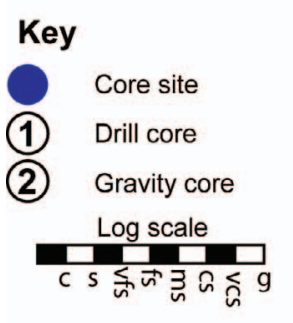

Data combinations
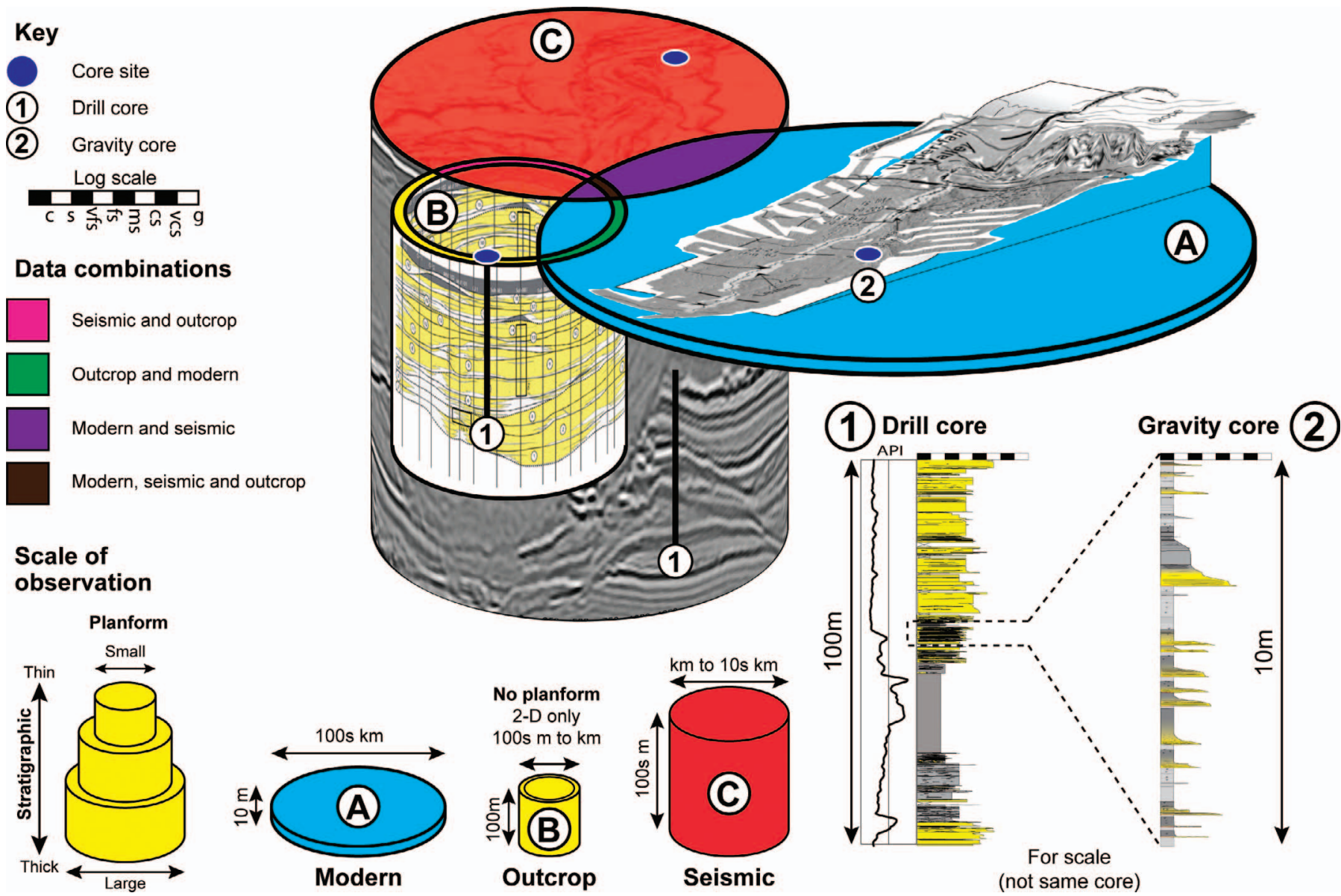

FIG. 2.-Venn diagram illustrating the three main types of field data that describe deep-water systems, highlighting their relative planform (circle diameter) and stratigraphic (cylinder depth) scales of observation (see main text for details). A) Modern seafloor data provides large explicit planform architectures and very limited information on stratigraphy (sonar imagery adapted from Babonneau et al. 2010). B) Outcrop data is largely 2D, therefore planform architecture must be inferred, and may provide information on local stacking patterns (correlation panel adapted from McCauley and Hubbard 2013). C) Seismic data provides gross-scale information from both planform (3D only) and stratigraphic perspectives but is limited by resolution (planform image adapted from Deptuck et al. 2003). Drill and gravity cores are used to support these data, ground-truthing them with 1-D successions of facies. Note that integrating different data types is key to a better understanding of deepwater bypass.

following questions: (i) what are the key factors that influence sediment bypass?; (ii) What recognition criteria can be established to identify sediment bypass in the stratigraphic record? (iii) How do different zones of sediment bypass vary in character? (iv) Is it possible to quantify the volume of sediment bypassed?

\section{Process and Stratigraphic Terms}

The diversity of specialists working on deep-water systems means that similar terms are often used to mean different things. Such miscommunication is particularly evident between those using theoretical, experimental, or numerical approaches to understand sediment transport and deposition, and those charged with interpreting these processes from the geological record. We therefore outline the key terms we use herein to describe sediment bypass, drawing on input from both process and stratigraphic perspectives:

1. Bypassing flows transport their entire sediment load in suspension or traction, resulting in downslope sediment transfer with no depositional record at the geographic point or area of measurement.
2. Partially bypassing flows deposit a diminutive proportion of their sediment load and transport the remainder downslope, typically resulting in relatively thin deposits across the zone of sediment bypass. This definition covers a broad range of flow states from flows bypassing almost their entire sediment loads across the area of bypass, to more strongly depositional flows that generate thicker deposits across the area of bypass.

3. Depositional flows are in their most depositional state along their flow path, resulting in relatively thick deposits at the area of measurement compared to other locations along the flow pathway.

Sediment bypass zones are an expression of the balance between sediment transport and deposition, and substrate entrainment by numerous submarine flows along a tract. The following stratigraphic terms are employed herein:

1. Complete sediment bypass zones are associated with bypassing flows, resulting in no deposition. The stratigraphic record of this process may be negligible (cf. Stevenson et al. 2013) or solely manifest by erosion surfaces that were generated from the bypassing current (cf. Hubbard et al. 2014). 
2. Bypass-dominated zones are associated with bypassing and partially bypassing flows. The stratigraphic expression may be composite and complex, recorded by no deposition and erosion (as above), or with thin-bedded deposits.

3. Depositional zones are dominated by depositional flows, resulting in relatively thick deposits. This term is used in a relative sense to distinguish areas or intervals where deposits are thickest compared to other areas of the sediment flow pathway.

Given the dynamic nature of deep-water systems, these bypass zones are likely to be transitional and transient, and may evolve from one type to another in time and space.

\section{BYPASS CRITERIA FROM THEORETICAL, NUMERICAL, AND EXPERIMENTAL APPROACHES}

Previous studies have not attempted to link deposits interpreted to be products of sediment bypass with processes of sediment transport and deposition simulated in theoretical, numerical, and experimental models. Consequently, our understanding of the physical parameters that influence the timing, location, and stratigraphic expression of bypass is limited. Here, the processes that drive sediment bypass in submarine flows from theoretical, numerical, and experimental approaches are examined.

\section{Proposed Bypass Criteria}

A number of theoretical and numerical approaches link the properties of submarine flows with their ability to bypass sediment. We outline these approaches and highlight four common influential parameters: grain size, sediment concentration, slope, and flow size. These common parameters provide a framework to better understand the processes governing sediment bypass in deep-water systems.

Rouse (Ro).--Rouse (1937) presented a landmark solution for the distribution of suspended sediment in a shear flow, whereby a nondimensional number balances the shear velocity of the transporting flow with the settling velocity of sediment:

$$
\mathrm{Ro}=\frac{v_{s}}{\kappa u^{*}}
$$

where, $v_{s}$ is the settling velocity of sediment particles $[\mathrm{m} / \mathrm{s}], \kappa$ is the von Kármán constant $[0.41]$, and $u^{*}$ is the shear velocity $[\mathrm{m} / \mathrm{s}]$. There is no value for Ro that signifies a threshold for suspension, but significant suspension occurs at Ro $<\sim 2$ or $u^{*} / v_{s}>\sim 1$, with suspension of grains in the lowest $10 \%$ of free surface flows at Rouse numbers as high as $5\left(u * / v_{s}\right.$ $=0.5$; van Rijn 1993). This simple criterion considers the main controls on sediment bypass to be sediment concentration, slope, and flow size. Of these, concentration, flow size, and slope are the three main variables governing the shear velocity, which can be approximated by:

$$
u^{*}=\sqrt{g\left(\rho_{f} / \rho_{i}-1\right) H_{r} S}
$$

where $g$ is the acceleration due to gravity $\left[\mathrm{m} / \mathrm{s}^{2}\right], \rho$ is the density $\left[\mathrm{kg} / \mathrm{m}^{3}\right]$ with the indices indicating the interstitial and ambient fluid $(i)$ and bulk flow $(f), H_{r}$ is the hydraulic radius of the flow [m], and $S$ is the slope. In the Ro criterion, these three parameters have a positive correlation with sediment bypass. In contrast, grain size is the main variable controlling settling velocity $\left(v_{s}\right)$, which has an inverse relation with sediment bypass (Eq. 1).

Capacity ( $\boldsymbol{\Lambda}$ ).-Leeder et al. (2005) state that Ro expresses the ability of flows to suspend and bypass grains of a certain size (i.e., flow competence) but does not provide information on the amount of sediment that can be kept in suspension (i.e., flow capacity). Hence, Leeder et al. (2005) propose a dynamic suspension criterion that does not contain grain size as a term, instead relating the lift of the vertical Reynolds stress component $\tau_{v v}$ to the downward gravitational forces on the sediment (Bagnold 1966; Leeder 1983; Leeder et al. 2005):

$$
\Lambda=\frac{\rho_{f} u^{* 2}}{m\left(\rho_{s} / \rho_{i}-1\right) g} \geq 1
$$

where $m$ is the suspended mass of sediment per unit bed area $\left[\mathrm{kg} / \mathrm{m}^{2}\right]$ with $\rho_{s}$ the density of solid particles in the flow. With respect to Equation 3 of Leeder et al. (2005), the densities have been reorganized to make $\Lambda$ dimensionless. Flow size and concentration are precisely cancelled out due to their relation with $u^{*}$ and $m$, leaving slope (i.e., $u^{*}$ via Eq. 2 ) as the main controlling variable on sediment bypass.

Ignition.-Pantin and Franklin (2009) investigated the energy budget of a developing flow under the simplifications of averaging the mass, volume, momentum, and turbulent kinetic energy (TKE) over the depth of the flow. From a four-equation model (Pantin 1979; Parker 1982; Parker et al. 1986) they isolate the spatial change in TKE to yield a criterion that can be interpreted to signify diminishing turbulence and depletion of the sediment in suspension for negative values, and increasing turbulence and erosion of sediment for positive values:

$$
\frac{e_{w}(1-R i)}{2}+\frac{u^{* 2}}{U^{2}}-\frac{e_{w} K}{U^{2}}-\frac{\varepsilon_{0} H}{U^{3}}-\frac{R i v_{s}}{U}=0
$$

where, $e_{\mathrm{w}}$ is the water entrainment coefficient [-], $\mathrm{Ri}$ is the bulk Richardson number $\left(\mathrm{Ri}=g\left(\rho_{f} / \rho_{i}-1\right) H / U^{2}, H\right.$ is the flow height [m], $U$ is the average velocity $[\mathrm{m} / \mathrm{s}], K$ is the TKE per unit mass $\left[\mathrm{m}^{2} / \mathrm{s}^{2}\right]$, and $\varepsilon_{0}$ is the rate of viscous dissipation of turbulence $\left[\mathrm{m}^{2} / \mathrm{s}^{3}\right]$. For subcritical flow $(\mathrm{Ri}>1)$ the first term is negative, and the only remaining positive term is the drag coefficient $\left(u^{* 2} / U^{2}\right.$; of order $10^{-3}$ to $10^{-2}$ ). In such flows the LHS of Equation 4 is always negative, meaning diminishing turbulence and flow-power downstream. Under supercritical flow conditions $(\mathrm{Ri}<1)$, this criterion develops a division in parameter space between depositing and eroding flows, "the ignition condition." This is an unstable bypass situation, meaning that small perturbations will grow and the flow will become either depletive with decreasing flow power downstream or erosional with increasing flow power downstream. Grain size appears in the $5^{\text {th }}$ term, where larger grains will again make the flow less prone to bypass. Flow size, sediment concentration, and slope have a presence in all other terms $\left(e_{w}, \mathrm{Ri}, u^{*}, U, K, \varepsilon_{0}\right.$, and $\left.H\right)$, and the variety of their occurrence makes Equation 4 challenging in terms of understanding how individual factors influence sediment bypass.

Flow Stratification and Turbulence Suppression.- "Direct numerical simulation" (DNS) has been used to probe the effect of vertical gradients in the concentration of settling sediment ("stratification") on turbulence suppression (Cantero et al. 2009; Cantero et al. 2012a; Cantero et al. 2012b; Cantero et al. 2014). According to these contributions, turbulence in suspensions can be maintained when

$$
\frac{\mathrm{Ri}_{\tau} \tilde{v}_{s}}{\mathrm{~K}_{\mathrm{c}}\left\{\mathrm{Re}_{\tau}\right\}}<1
$$

where the subscript $\tau$ denotes the shear Richardson and Reynolds flow scales:

$$
\mathrm{Ri}_{\tau}=\frac{g\left(\rho_{s} / \rho_{i}-1\right) C H}{u^{* 2}} \text { and } \operatorname{Re}_{\tau}=\frac{u^{*} H}{\eta}
$$

where $C$ is the sediment concentration. The settling velocity $\left(v_{s}\right)$ in Equation 5 has been made nondimensional by 
TABLE 1.-Comparison of theoretical and numerical approaches outlined in this paper to experiments of Cartigny et al. (2013). Values used in the criteria were established with properties measured over the duration of the flows (speed, turbulence, and thickness) and those set by the experimental conditions (slope and grain size). Note that all criteria struggle in the prediction of sediment bypass in the experiments. The stratified suppression criterion is close to the proposed threshold of 1 , and in this case the disparity could be due to errors in parameter estimation from the experiments

(e.g., flow speed or thickness).

\begin{tabular}{lcccc}
\hline \hline \multicolumn{1}{c}{ Criterion } & $\begin{array}{c}\text { Prediction } \\
\text { for Bypass }\end{array}$ & $\begin{array}{c}\text { Prediction for } \\
\text { Deposition }\end{array}$ & $\begin{array}{c}\text { Experiments Consistent } \\
\text { with Prediction }\end{array}$ & $\begin{array}{c}\text { Error in Parameter } \\
\text { Estimation from Experiment }\end{array}$ \\
\hline Ro $\left(u^{*} / v_{s}\right)$ (Eq. 1) & 2.7 & 2.4 & No & Small \\
$\Lambda($ Eq. 3) & 0.024 & 0.020 & No & Moderate \\
Ignition (Eq. 4) & -0.036 & -0.039 & Very large & Moderate \\
Stratified-suppression (Eq. 5) & 1.2 & 1.5 & Close & Mo \\
\hline
\end{tabular}

$$
\tilde{v}_{s}=\frac{v_{s}}{u^{*}}
$$

and the weak dependence of the turbulence threshold value on the Reynolds number has tentatively been extended far beyond the reach of DNS simulations as (Cantero et al. 2012b):

$$
K_{c}=0.041 \ln \left(\mathrm{Re}_{\tau}\right)+0.11
$$

The experiments show that turbulence at the base of the flows is rapidly and completely extinguished if the term on the LHS of Equation 5 becomes larger than 1. Although sedimentation is not actually modeled, the inference of a simulation with no turbulence at the base is that sediment suspension cannot be sustained, and that such flows would rapidly deposit their sediment loads. Equation 5 essentially combines a Rouse-type criterion for sediment suspension with a Richardson scale of the flow. Since the latter contains the total amount of sediment in suspension (Eq. 6), this criterion unifies both the competence for suspension and the capacity to suspend a specified amount of sediment. Again, all four parameters of grain size, sediment concentration, slope, and flow size appear in the criterion.

\section{Comparison of Criteria to Experiments}

Attempts have been made to test the criteria discussed above individually, with variable success (van Rijn 1984; van Rijn 1993; Pantin 2001; Pantin and Franklin 2011; Cantero et al. 2012b), but none of these entail a comparison with flows that are able to actually bypass sediment. Cartigny et al. (2013) present a series of scaled experiments of highconcentration sand-laden flows from either side of the bypass condition, i.e., depositional or bypassing. The criteria outlined above do not predict the bypass condition in these experiments (Table 1). However, the stratified-suppression criterion produces bypass threshold values that are very close to the experimental observations (within estimated error). This comparison highlights that, although process models of bypass incorporate common factors of grain size, sediment concentration, slope, and flow size, there is not yet a consistent framework of experiments, theory, and numerical models that accurately predicts sediment bypass. Four approaches have been discussed here, and only the stratifiedsuppression threshold approach yields encouraging predictions of the bypassing nature of sand-laden experimental flows.

\section{EXPRESSION OF BYPASS IN MODERN DEEP-WATER SYSTEMS}

The modern seafloor provides a wealth of information on deep-water clastic systems through high-resolution mapping and extensive coring, which has enabled their planform geometry and associated depositional architectures to be constrained in considerable detail over large areas; particularly well-studied systems include the Amazon Fan (e.g., Damuth and Kumar 1975; Damuth et al. 1983, 1988; Flood 1987; Pirmez and Flood 1995), Navy Fan (e.g., Normark et al. 1979; Piper and Normark 1983), the Mississippi Fan (Garrison et al. 1982; Kastens and Shor 1985; Twichell et al. 1991, 1992), the Zaire Fan (Droz et al. 1996; Savoye et al. 2000; Babonneau et al. 2002, 2010) and the Bengal Fan (Curray et al. 2002; Schwenk et al. 2003, 2005; Kolla et al. 2012). Surface mapping generally considers decimeter scale stratigraphy of years to 100s years; near-surface mapping commonly captures 10 s of meters of stratigraphy of 1 to 100 s kyr; shallow and deep drill cores can provide centimeter scale stratigraphic records over 100s of meters representing millions of years of sedimentation (Normark et al. 1979; Mutti and Normark 1987; Piper and Normark 2001). The high level of planform detail afforded in these modern deep-water systems allows anatomical links to be made between proximal and distal areas. This aids interpretation of sediment bypass zones by linking them down-system with areas of sediment deposition. For example, the Congo Channel extends across the Zaire Fan for $760 \mathrm{~km}$ (Babonneau et al. 2002). Within the channel axis, $>5 \mathrm{~m}$ of amalgamated, structureless sands are present (Babonneau et al. 2010). The channel passes down-system into a submarine lobe complex, the youngest of which is sand-rich (Savoye et al. 2000), suggesting that the modern channel is an efficient conduit for sediment transport (Fig. 3A). Amalgamated structureless sands in the channel axis can therefore be attributed to partially bypassing flows, where coarse-grained hyperconcentrated near-bed layers deposit the structureless sands, whilst the finergrained upper parts of the flow are bypassed down-system (Lowe 1982).

However, despite good anatomical links between different parts of the Zaire Fan system and a speculative association between structureless sands and sediment bypass, high-resolution stratigraphic links between the deposits found in the channel and sand bodies documented farther down slope are difficult to constrain. Hence, it is not demonstrable that specific sedimentary facies or stratigraphic surfaces found in the channel actually relate to specific sand bodies found down slope (Fig. 3B). External levees adjacent to modern submarine channels contain a coeval and more complete depositional record. For example, the currently inactive Amazon Channel has thick channel-levee deposits that border and confine the channel system for almost its entire length $(\sim 800 \mathrm{~km})$, and yet the channel thalweg itself is underfilled (Hiscott et al. 1997).

An improved understanding of deep-water sediment bypass has been achieved through correlations that connect up-system areas of sediment bypass with strata deposited farther down-system in the Moroccan Turbidite System (Fig. 4A; Wynn et al. 2002b; Talling et al. 2007; Stevenson et al. 2014a). Correlating individual beds along their depositional extent makes it possible to estimate total sediment volumes, as well as the amount of sediment bypassed at various locations along the system (Fig. 4B). From cores, the sedimentary facies associated with 


\section{A Upslope and downslope facies are stratigraphically related}

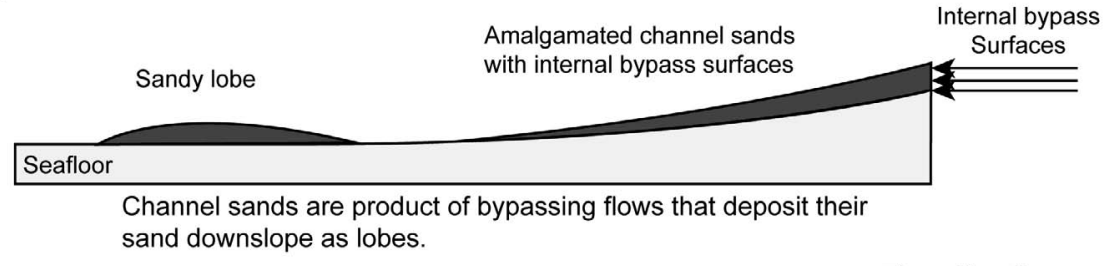

sand downslope as lobes.

Flow direction

\section{B Upslope and downslope facies are not stratigraphically related}

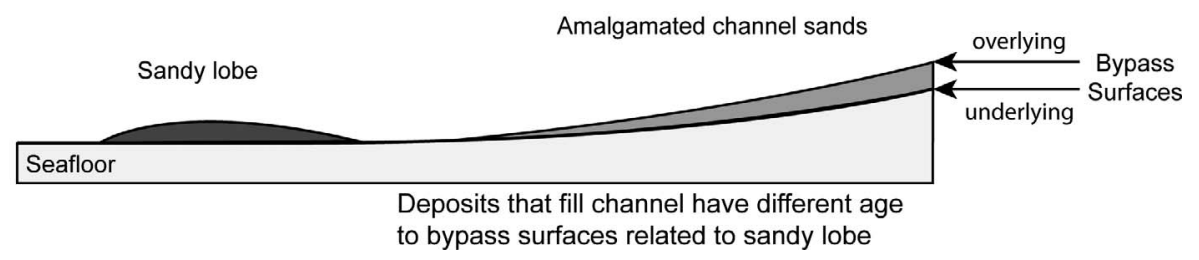

FIG. 3.-Two models of the Zaire Fan showing different interpretations of the temporal relationship between upslope amalgamated channel sands and downslope sand-rich lobes. A) Amalgamated channel sands are stratigraphically related to downslope sand-rich lobes. Bypass surfaces are found in the amalgamated channel sands and are difficult to detect. B) Amalgamated channel sands are of an age different from that of the sand-rich lobe. The amalgamated channel sands are underlain (younger) and/or overlain (older) by sediment bypass surfaces related to the deposition of the sand-rich lobe. areas dominated by sediment bypass can be examined. The deposits of one submarine flow (Bed 5; Fig. 5) reveal: 1) the general sedimentological and stratigraphic expression of two distinct bypass-dominated zones in the Moroccan Turbidite System, and 2) how grain-size breaks within the bed can be used as an indicator of sediment bypass in basin-floor deposits. The Bed 5 event occurred at $\sim 60 \mathrm{ka}$ and most likely originated from the Moroccan Margin in the head of the Agadir Canyon (Wynn et al. 2002b). The flow deposited approximately $52 \mathrm{~km}^{3}$ of sediment $\left(21 \mathrm{~km}^{3}\right.$ sand and $31 \mathrm{~km}^{3}$ mud) along an $\sim 1500-\mathrm{km}$-long pathway from the Agadir Canyon, across the Agadir Basin, through the Madeira Channel System, and onto the Madeira Abyssal Plain (Fig. 4) (Wynn et al. 2002b; Wynn et al. 2010).

The Moroccan Turbidite System case study describes two distinct bypass-dominated zones with characteristic facies situated proximally at the base of slope, and distally on the basin floor. During the Bed 5 event, both of these zones were bypassed by large volumes $\left(\sim 52\right.$ and $30 \mathrm{~km}^{3}$ respectively) of sediment. The base-of-slope bypass-dominated zone is located close to the mouth of the Agadir Canyon (Fig. 4A, B), where Bed 5 deposits drape scour surfaces with $8-15 \mathrm{~cm}$ of very fine sands that grade normally into silt and mud; where no scour surfaces are observed, thin $(2-5 \mathrm{~cm})$ gravel layers are present (Fig. 5A) (Talling et al. 2007; Wynn et al. 2010; MacDonald et al. 2011). These deposits grade down slope over approximately $30 \mathrm{~km}$ into thicker $(50-100 \mathrm{~cm})$ medium and coarse sands, which extend for $\sim 200 \mathrm{~km}$ along the length of the Agadir Basin before grading into fine sands (Fig. 5B) (Talling et al. 2007; Wynn et al. 2010; Stevenson et al. 2014b).

Benthic foraminifera species found in Bed 5 show that approximately $20 \%$ of the total bed volume $\left(\sim 10 \mathrm{~km}^{3}\right)$ comprises species entrained into the flow via erosion at water depths greater than $2500 \mathrm{~m}$, suggesting that the scours in this bypass-dominated zone were formed and/or modified by the Bed 5 event (Talling et al. 2007). Almost the entire bed volume $\left(\sim 52 \mathrm{~km}^{3}\right)$ is found farther down slope, across the Agadir Basin and the Madeira Abyssal Plain (Wynn et al. 2002b; Frenz et al. 2008; Wynn et al. 2010; Wynn et al. 2012; Stevenson et al. 2014a). Hence, deposits found in the area close to the mouth of the Agadir Canyon represent only a tiny fraction of the total sediment carried by the flow $(<0.8 \%)$.

A second bypass-dominated zone is present approximately $250 \mathrm{~km}$ downslope, where flows pass from the Agadir Basin with a slope of $\sim 0.02^{\circ}$ into the high-aspect-ratio (250:1) Madeira Channel System with a slope of $\sim 0.06$ (Fig. 4B) (Stevenson et al. 2013). Deposits of Bed 5 in the Agadir Basin comprise relatively thick $(50-100 \mathrm{~cm})$ ungraded coarse to fine sands (Fig. 4A, B), which extend across the entire $100 \mathrm{~km}$ width of the basin (Talling et al. 2007; Frenz et al. 2008). The flow was approximately $100 \mathrm{~km}$ wide as it approached the head of the Madeira Channel System. Therefore, only parts of the flow were confined by the $\sim 5$-km-wide channels, whilst the remainder spread across the channel margins and interchannel highs. In relatively proximal (up to $\sim 50 \mathrm{~km}$ from the SW extent of the Agadir Basin) areas of the Madeira Channel System there is no expression of Bed 5 in the channel axes, either as an erosional hiatus or as a deposit of sand or mud (Stevenson et al. 2013) (Fig. 5B). However, along the margins of the channels (i.e., the unconfined seafloor) Bed 5 develops laterally extensive (10's $\mathrm{km}$ ), thin $(10-15 \mathrm{~cm})$, planar- and ripple-laminated fine sands with inversely graded bases, which are sharply overlain by very thin $(1-2 \mathrm{~cm})$ mud caps (Fig. 5B). These deposits correlate with normally graded rippled fine sands present 150-700 km down slope (Stevenson et al. 2013).

Grain-size breaks are common in submarine flow deposits throughout the Moroccan Turbidite System (Sumner et al. 2012; Stevenson et al. 2014a, 2014b). They occur as sharp surfaces between: coarse-grained structureless sands overlain by finer-grained sands, often with planar lamination (Type I); inversely graded sands overlain by finer-grained sands (Type II); iii) planar-laminated sands overlain by finer-grained ripple cross-laminated sands (Type III); sand overlain by mud (Type IV), and; mud-rich sand overlain by mud (Type $V$ ) (Fig. 4; cf. Stevenson et al. 2014a). In proximal basin-floor localities, Type I, II, III, and $I V$ grain-size breaks are common, forming composite vertical grading profiles in the deposits (e.g., Fig. 5A; Core 50). In more distal localities, sand deposits generally have simple normal grading profiles overlain by Type $I V$ or $V$ grain-size breaks from sand to mud (e.g., Fig. 5B; Cores P36 and 12). By mapping out individual beds for large distances, several studies de monstrate that grain sizes missing across grain-size breaks in relatively proximal areas are found farther down-system (Amy et al. 2000, 2007; Sumner et al. 2012; Stevenson et al. 2014a). Hence, in proximal areas, these grain sizes must have been bypassed, meaning grain-size breaks represent internal bypass surfaces within a single event bed.

Modern seafloor data provide regional, high-resolution images of the planform morphologies of deep-water systems (Fig. 2A). Facies recorded in cores then allow deposits to be associated with particular fan environments of known slope and confinement, and in rare cases, the spatial evolution of stratigraphically equivalent deposits down slope. This 

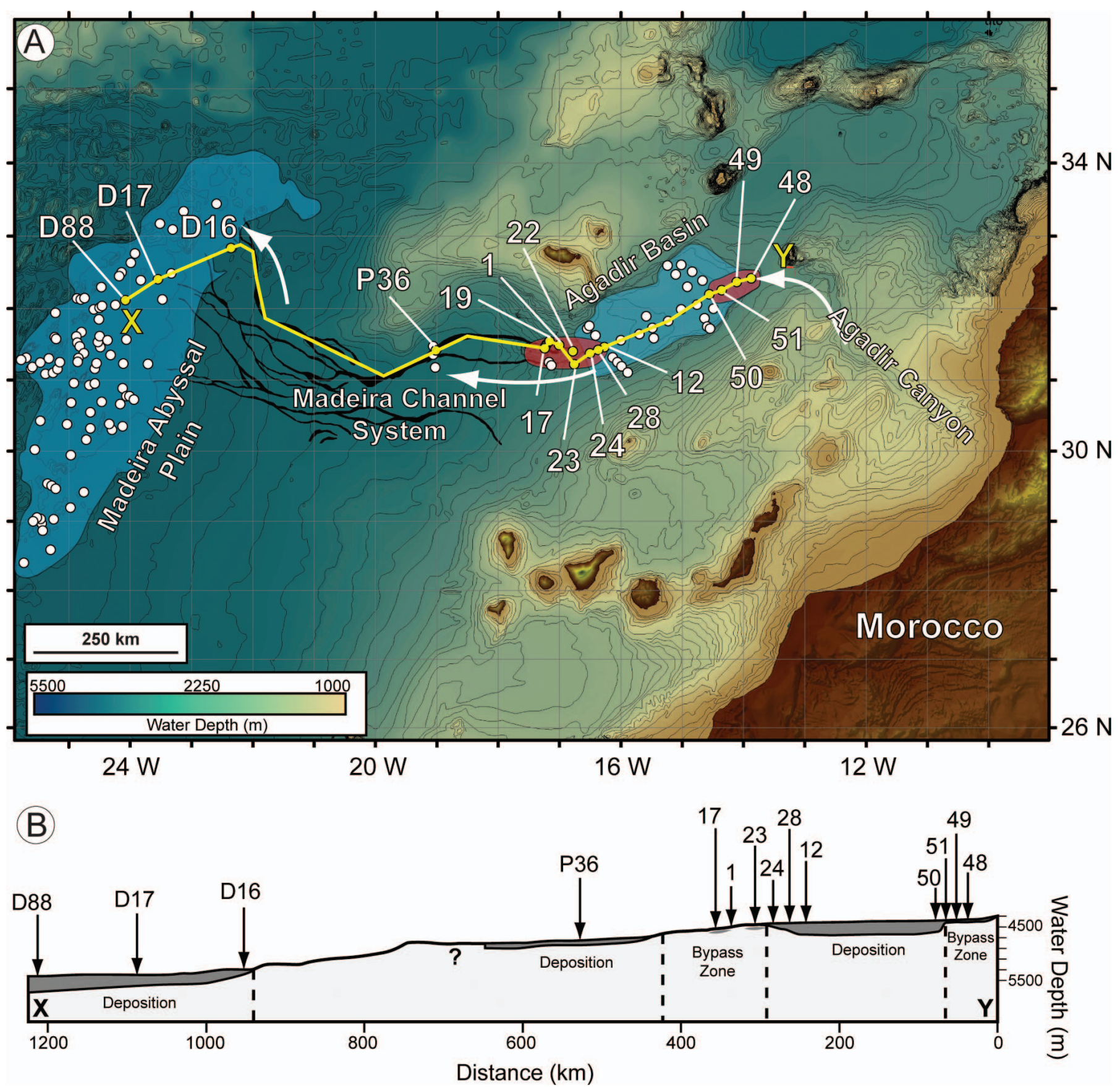

FIG. 4.-A) Map of the Moroccan Turbidite System showing the pathway of Bed 5 through the Agadir Canyon, into the Agadir Basin, through the Madeira Channel System (MCS), and ultimately spreading across the Madeira Abyssal Plain (adapted from Stevenson et al. 2014a). Shallow sediment cores taken across the system are marked as white circles, with those detailed in this study highlighted in yellow. Base-of-slope and basin-floor bypass zones are highlighted as red areas. B) Schematic core transect of Bed 5 along its pathway from the Agadir Canyon to the Madeira Abyssal Plain. Sediment bypass zones highlighted in Part A are labelled.

information is valuable to those working in outcrop, where lateral exposure limits our understanding of paleoenvironment, and the spatial variability of deposits down-system. However, modern datasets typically describe fine-grained systems and utilize relatively short (generally $<10 \mathrm{~m}$ ) cores (Fig. 2A; Core 2), which limits our understanding of coarser-grained facies (sands), lateral facies variability, and the largerscale stratigraphic evolution of deep-water systems.

\section{EXPRESSION OF BYPASS IN OUTCROP}

Exposures of ancient deep-water systems provide a complementary dataset to the modern sea-floor because: 1) they typically have a sandrich bias due to the poor weathering of fine-grained rocks, 2) facies can be described laterally over 10 s to 100 s of meters, and 3) stratigraphic context can be established from successions 100s of meters thick (Fig. 2B). Consequently, there are a range of spatial and 


\section{(A)}

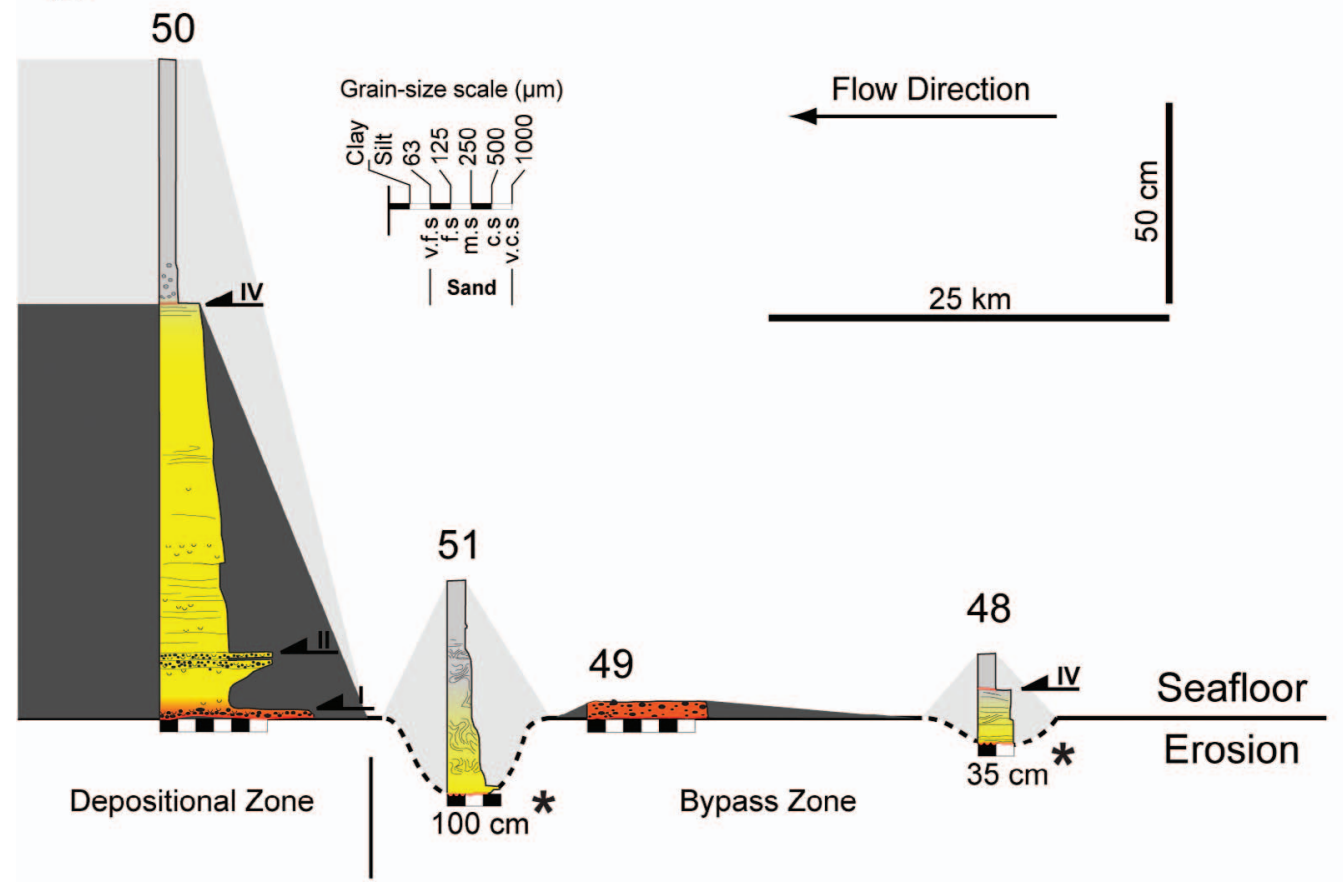

\begin{tabular}{|c|c|}
\hline \multicolumn{2}{|c|}{ Sedimentary Structures } \\
\hline Graphic & Description \\
\hline & Structureless \\
\hline & Granules/Pebbles \\
\hline & Mud clasts \\
\hline & Parallel lamination \\
\hline & $\begin{array}{l}\text { Ripple cross } \\
\text { lamination }\end{array}$ \\
\hline & $\begin{array}{l}\text { Contorted } \\
\text { lamination }\end{array}$ \\
\hline & $\begin{array}{c}\text { Grain-size break } \\
\text { (Type I to IV) }\end{array}$ \\
\hline & Hiatus \\
\hline & Gravel \\
\hline & Clean Sand \\
\hline & Mud-Rich Sand \\
\hline & Mud \\
\hline
\end{tabular}

(B)

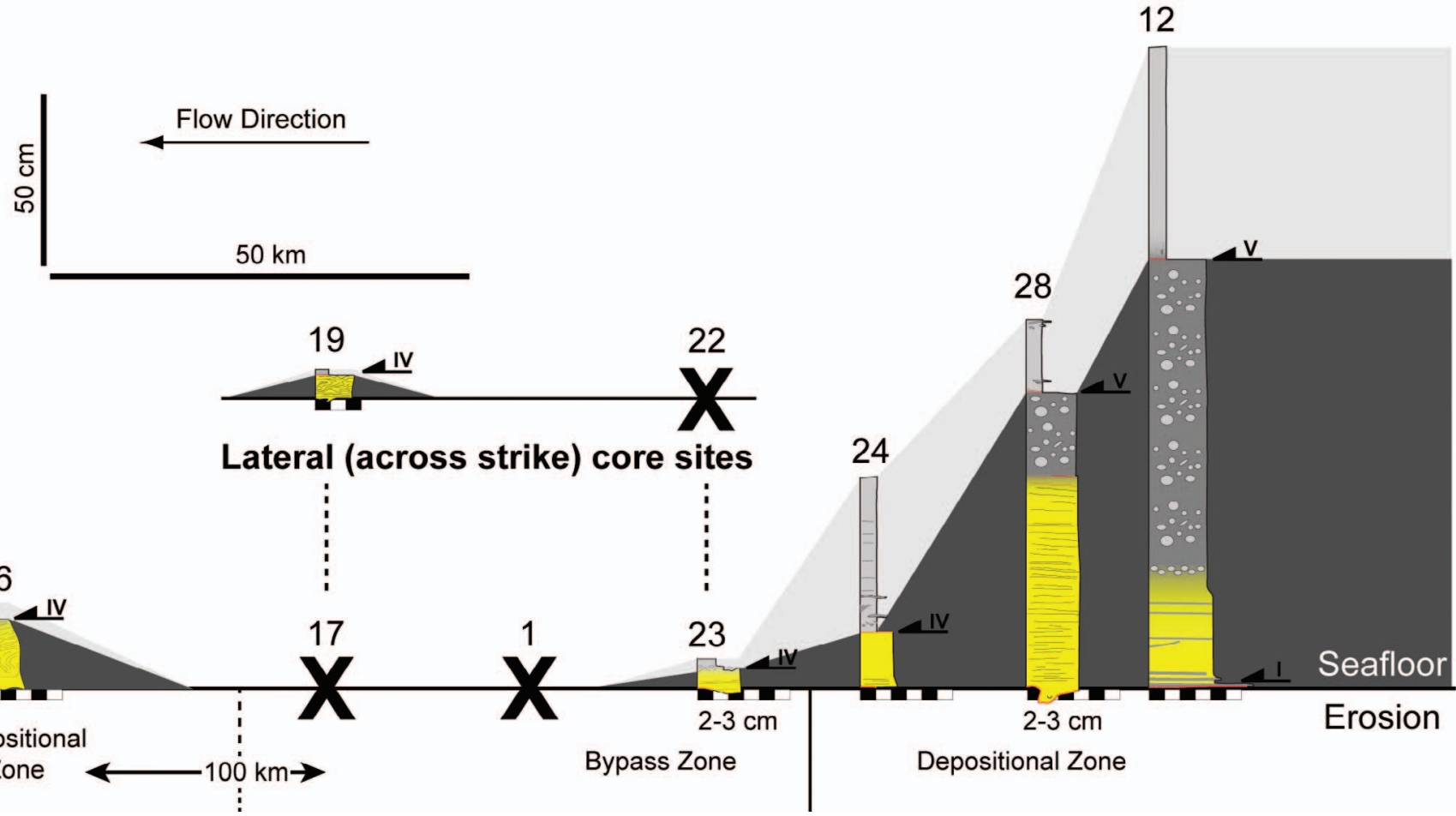

FIG. 5.-Core transects showing deposits of Bed 5 through two zones of sediment bypass (adapted from Talling et al. 2007; Wynn et al. 2010; Stevenson et al. 2013). A) Base-of-slope bypass zone, or CLTZ, close to the mouth of the Agadir Canyon, which comprises common erosional scours overlain by relatively fine-grained sands and muds, and thin gravel lags with no mud caps. The sediment bypass zone extends for $\sim 50 \mathrm{~km}$ downslope, then scouring stops and deposits become thicker (core 50 ). B) Basin-floor bypass zone across the Madeira Channel System, where there is an increase in slope from the Agadir Basin $\left(0.02^{\circ}\right)$ to the Madeira Channels $\left(0.06^{\circ}\right)$, and parts of the flows are confined by channels. It is common that no trace of Bed 5 is found, across the proximal open slope (core sites 1 and 22) and in the channels (core site 17). However, lateral (across strike) to nondepositional areas, deposits are found comprising thin, inversely graded, planar-laminated and ripple cross-laminated sands overlain by a sharp grain-size break and almost no mud cap (core sites 23-22 and 17-19). Note change in length scale from core site 17 to P36. 

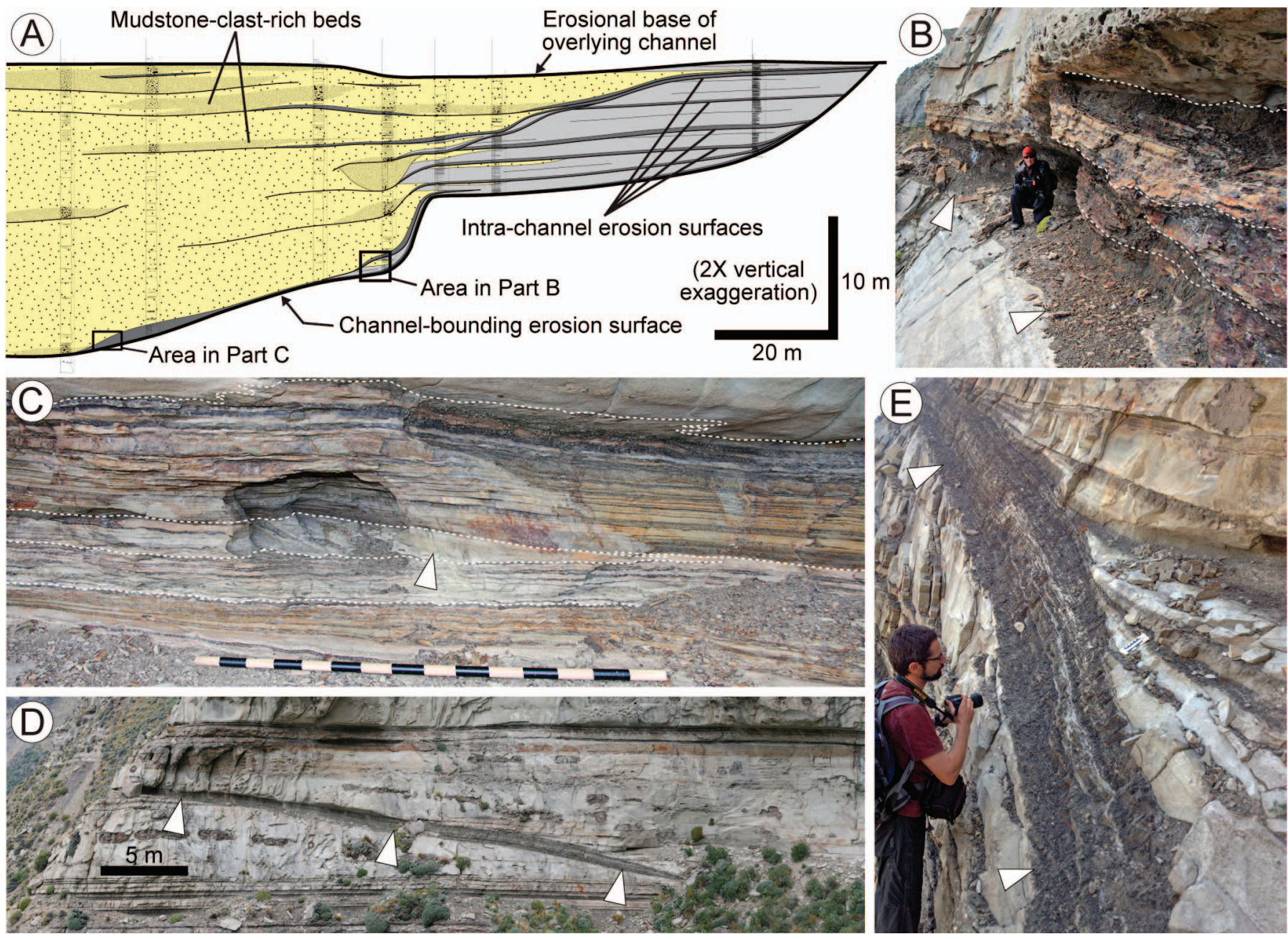

Fig. 6.-Evidence for sediment bypass from the Tres Pasos Formation outcrop belt, Magallanes Basin, Chile.A) Slope-channel cross section highlighting the shift from sandstone-dominated to siltstone-dominated strata from channel axis (left) to margin (right), as well as numerous intrachannel erosion surfaces (modified from Hubbard et al. 2014). The complicated intrachannel strata indicate a protracted history of erosion, sediment bypass, and deposition within the conduit, before ultimately being filled. B) An erosional channel base (indicated by arrows) overlain by thinly interbedded siltstone and sandstone. The recessive, composite unit that drapes the channel base is characterized by numerous internal erosion surfaces (dashed lines), which are thought to have been incised when coarse-grained sediment was bypassed basinward. The location of the photograph is indicated by a rectangle in Part A. C) Composite package of laminated siltstone and sandstone draping a channel base, with crossstratification delineated by the white arrow. The location of the photo is indicated by a rectangle in Part A. D) Siltstone bedset overlying a channel base (delineated by triangles). E) A close-up perspective of the bedset highlighted in Part D, showing that beds parallel the underlying, inclined channel-base erosion surface. Thick sandstone beds pinch out to the left (towards the channel margin), yet the turbidite caps (Bouma Td-e) persist and contribute to the overall thickness of the drape unit.

stratigraphic scales to be considered, from bed scales (centimeters to meters) and sedimentary-body scales (10s to $100 \mathrm{~s} \mathrm{~m})$ to system and basin scales (10s to $100 \mathrm{~s} \mathrm{~km})$.

Sedimentary facies interpreted as indicators of sediment bypass have been described within slope-channel and base-of-slope (CTLZs) settings. Using high-quality field data, primarily from the Cretaceous Tres Pasos Formation, Chile (Hubbard et al. 2010), we outline the outcrop expression of sediment bypass in these environments.

\section{Bed Scale Facies: Draped Erosion Surfaces}

Scour- and channel-form bodies are defined by an erosional basal surface that truncates underlying strata. Such surfaces are often draped by centimeter to decimeter thick packages of thin-bedded (centimeters thick) fine-grained mudstone, siltstone, and very-fine sandstone (Fig. 6) (Mutti and Normark 1987; Elliott 2000; Gardner and Borer 2000; Grecula et al. 2003; Gardner et al. 2003; Mayall et al. 2006; Barton et al.
2010; Di Celma et al. 2010; Pyles et al. 2010; Brunt et al. 2013; Macauley and Hubbard 2013; Hubbard et al. 2014; Ito et al. 2014). These deposits are typically characterized by horizontal lamination, ripples, or structureless mudstone, and rarely low- to high-angle cross-lamination (Fig 5). In some instances, thin (centimeters) and discontinuous lags of coarsegrained sediment are interstratified with the otherwise fine-grained facies (e.g., Beaubouef et al. 1999). Typically channel base drape units are poorly preserved because of truncation by younger erosion surfaces, which are overlain by sandstones (Fig. 6A; Macauley and Hubbard 2013).

If a flow is erosive (entraining substrate), then its capacity has exceeded its sediment load and de facto must be bypassing as erosion is taking place. Hence, the presence of composite or isolated erosion surfaces in a succession indicates bypass of sediment down-system. Mutti and Normark (1987) considered mud draping erosion surfaces to be the product of longitudinal variations in flow behavior over a fixed geographical point. Their premise was that the head and body of 
a flow is erosive and bypassing, with deposition from the fine-grained tail; the erosion and mud drape providing the only evidence of its passing.

\section{Bed Scale Facies: Coarse-Grained Lag Deposits}

Lenticular beds or bodies composed of extrabasinal pebble-, granule-, or coarse sand-size grains, and/or intrabasinal sedimentary clasts, are common in axial channel fills (Fig. 7A, B, C, F) (Mutti and Normark 1987; Gardner et al. 2003; Beaubouef 2004). They are sharp-based (often undulatory), are commonly planar laminated or cross-stratified, and can range from $10 \mathrm{~cm}$ to many meters thick (e.g., O'Byrne et al. 2007; Jobe et al. 2010). Large-scale cross-stratification (bed sets $>1-2 \mathrm{~m}$ thick) in these deposits can accrete upstream (e.g., Pickering et al. 2001) or downstream (e.g., Winn and Dott 1977) (Fig. 7A, B). In rare instances, dune-scale (up to $1 \mathrm{~m}$ thick) cross-bedding with mud drapes between foresets characterizes lenticular, coarse-grained turbidite sandstones (Hubert 1966; Keith and Friedman 1977; Mutti 1992; Amy et al. 2000, 2007; Sylvester and Lowe 2004).

Large-scale cross-stratification is interpreted to form through sustained bedload transport of sufficiently coarse-grained sediment beneath flows with relatively low aggradation rates (Allen 1982; Southard 1991), where all but the coarsest sediment is bypassed down-system (Mutti and Normark 1987). Therefore, the presence of cross-stratified coarse-grained sandstone and conglomeratic lag facies in basal slope-channel fills is interpreted to represent bypass, recording the role of these conduits in long-lived sediment transfer (Mutti 1992; Gardner et al. 2003; Hubbard et al. 2010, 2014; Pyles et al. 2010). Mud drapes between foresets indicate repeated intermittent downstream migration of the bedform (Allen 1982), which is interpreted to be the product of multiple flows partially bypassing all but their coarse-grained bed load and then depositing finegrained sediment from their dilute tails. Therefore, such facies present in base-of-slope (proximal basin-floor settings) indicates repeated bypass of sediment down-system (Mutti and Normark 1987; Mutti 1992; Amy et al. 2000, 2007).

\section{Bed Scale Facies: Trace Fossils at Exhumation Surfaces}

Because conduits for sediment transfer, such as channels, focus submarine flows, significant erosion on the seafloor can occur, removing soft, poorly compacted sediment, and exposing a semiconsolidated or firm substrate (Hubbard and Shultz 2008). This substrate is subject to colonization by burrowing organisms. Upon the death of the organisms, burrows remain open and are subject to filling by sediment derived from partially bypassing flows. In instances where the channel form is mudstone-filled, a record of coarse-grained sediment bypass in the conduit may be present in sandstone-filled trace fossils that subtend from the basal erosional surface (Fig. 7D, E) (Hubbard et al. 2012; Callow et al. 2014). The trace fossils most typically associated with "bypass assemblages" include unlined vertical to horizontal tubes (e.g., Skolithos, Planolites) that often comprise u-shaped structures (e.g., Arenicolites) that are sometimes spreitenated (e.g., Diplocraterion) (Hubbard et al. 2012; Callow et al. 2014).

\section{Sedimentary-Body Scale: Slope Channel Fill}

Channel fill varies from axis, off-axis, to margin (Fig. 6A). Channelaxis stratigraphy is commonly dominated by coarse-grained lags that can include mudstone breccia, which is overlain by amalgamated to nonamalgamated thick-bedded conglomerate- or sandstone-dominated facies (e.g., Normark 1978; Mutti 1992; Gardner et al. 2003; Mayall et al. 2006; Arnott 2007; Kane et al. 2007; DiCelma et al. 2010; Hodgson et al. 2011; Brunt et al. 2013). A progressive transition from amalgamated to nonamalgamated and thinner-bedded sandstone towards channel margins is notable (e.g., Mutti and Normark 1987; Macauley and Hubbard 2013). Fine-grained thin-bedded facies is preferentially preserved at the channel margins (Fig. 6A, B, D, E) (e.g., Mutti and Normark 1987; Beaubouef et al. 1999; Sullivan et al. 2000; Pyles et al. 2010; Macauley and Hubbard 2013; Hubbard et al. 2014; Stright et al. 2014).

Distinguishing between channel-axis and channel-margin drapes is important because channel-axis drapes record sediment bypass from the lower, axial parts of the flows, whilst channel-margin drapes record a lateral depositional record from the upper parts of the flows (Mutti and Normark 1987; Beaubouef et al. 1999; Hubbard et al. 2014). Hence, channel-margin drapes represent a coeval depositional record of sediment bypass within the channel-axis. Numerous erosion surfaces are recorded in the channel-axis fill and are occasionally preserved extending laterally into the channel margins where they are draped by fine-grained thinbedded facies (Fig. 6A). This indicates repeated and protracted bypass throughout the history of a channel, which is punctuated by depositional events (Hubbard et al. 2014). A reduction in the number of erosion surfaces and the degree of amalgamation upward suggests diminishing levels of bypass as a channel becomes filled (e.g., Brunt et al. 2013). Therefore, channel fills can represent significant amounts of sediment being bypassed down-system, despite local accumulations of thick-bedded coarse-grained facies.

\section{Sedimentary-Body Scale: Composite Channel Forms}

In large-scale outcrops, individual slope channel fills are bounded within larger stratigraphic channel-form surfaces (e.g., Hodgson et al. 2011). Initial incision and sculpting defines the bases of these highly composite surfaces (Mutti and Normark 1987; Beaubouef 2004; Kane et al. 2007; Di Celma et al. 2010; Di Celma et al. 2011; Hodgson et al. 2011; Fildani et al. 2013; Covault et al. 2014). In some instances, these surfaces are overlain by thick chaotically bedded deposits in outcrop, which are attributed to mass wasting (e.g., Crane and Lowe 2008; Macauley and Hubbard 2013). The composite and diachronous nature of these surfaces is direct evidence of repeated and prolonged periods of erosion and sediment bypass. Thus, composite channel-form bodies represent a significant amount of sediment bypass, which would have persisted during repeated phases of channel incision, maintenance, and fill.

\section{Sedimentary-Body Scale: External and Internal Levees}

Thick successions of fine-grained facies located adjacent to channel bodies are dominated by thin, normally graded turbidites and structureless to laminated mudstone beds. These units are attributed to channel overbank processes and flow stripping on external levees or internal levees, as well as to hemipelagic sedimentation (Winn and Dott 1979; Hickson and Lowe 2002; Kane et al. 2007, 2009a; Hubbard et al. 2008; Hodgson et al. 2011; Kane and Hodgson 2011; Morris et al. 2014).

Although levee deposits are not often considered to represent bypassrelated deposits per se, their origins from flow stripping and overspill at channel bends mean that they represent deposition from the fine-grained (upper) parts of flows passing through channels, where the coarse-grained (basal) components of the flows are confined within the channel axes and bypass downslope (Buffington 1952; Normark 1978; Piper and Normark 1983; Piper and Savoye 1993; Fildani et al. 2006; Kane et al. 2010). Hence, internal and external levees are coeval depositional records of sediment bypass within channels.

\section{Regional Scale: Stratigraphic Context}

Outcrops of ancient submarine slope systems that allow detailed, regional correlation of stratigraphic surfaces along slope-parallel, diporientated profiles provide a means to consider the expression and impact 

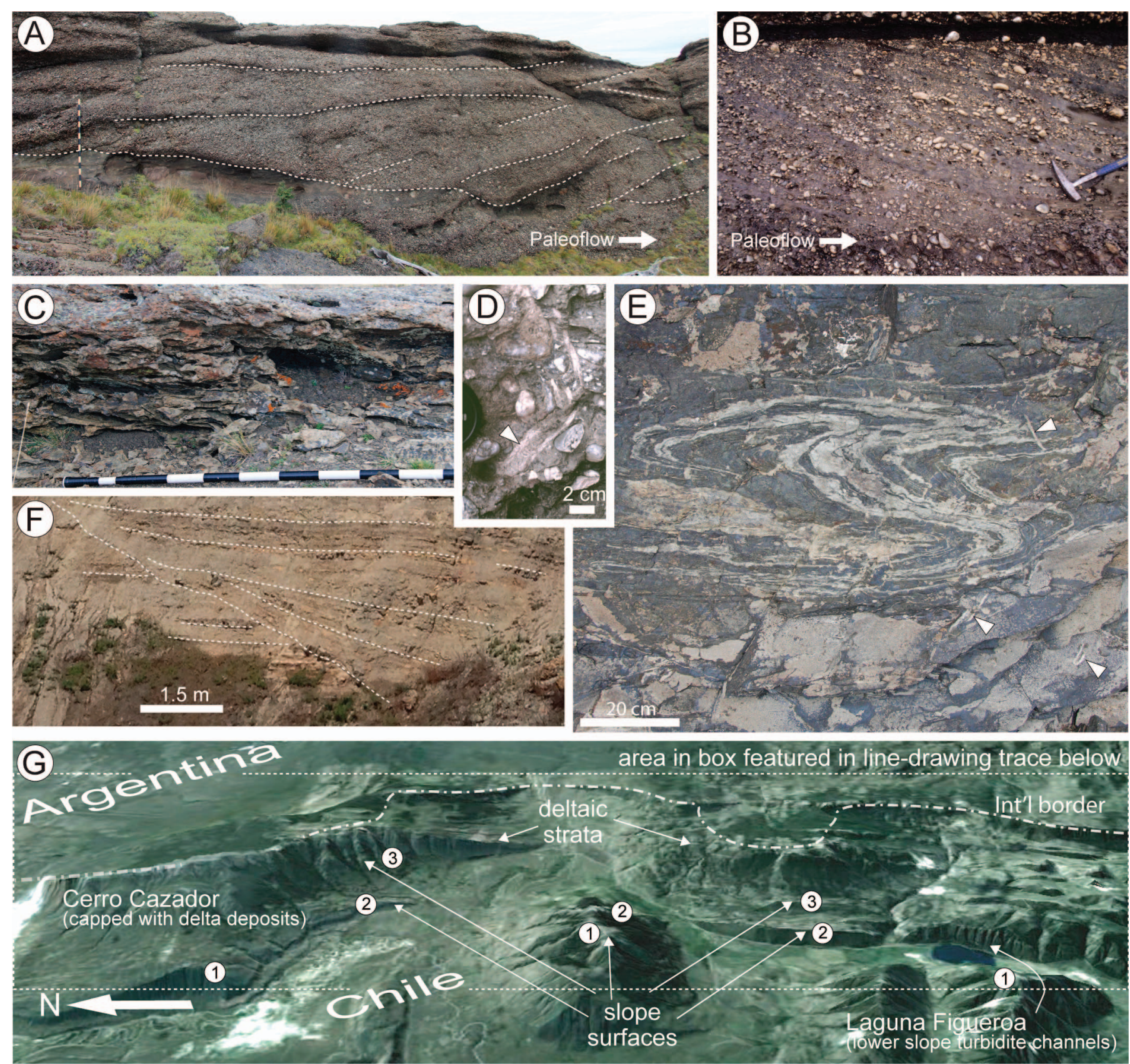

area in box featured in line-drawing trace below

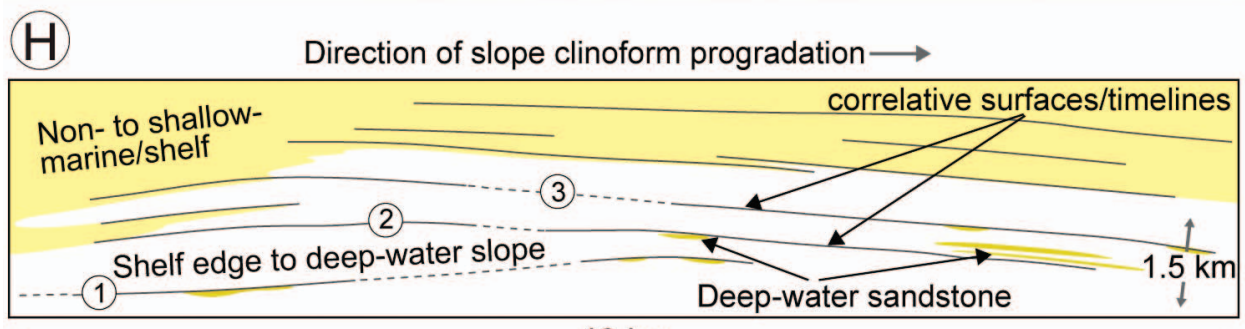

(1)

$40 \mathrm{~km}$

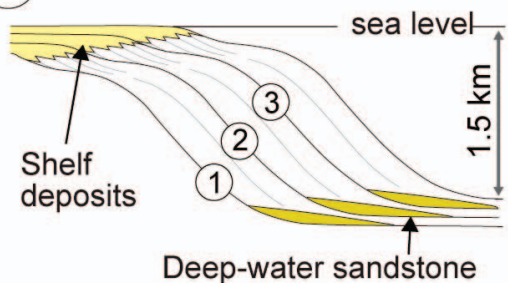

FIG. 7.-Evidence for sediment bypass from outcrop.A) Backstepping and B) forestepping cross-stratification in conglomeratic units of the deep-water Magallanes foreland basin, Chile. In both instances, sandstone beds are not a significant part of the sedimentary facies association, as large flows carried much of their sand and mud components farther basinward. Part A is from a slope clinothem in the Tres Pasos Formation, whereas Part B is from a channel deposit in the Cerro Toro Formation (cf.Winn and Dott 1977).C) Channel deposit, consisting of a lag composed of intrabasinal and extrabasinal clasts, as well as overlying abandonment mudstone (not shown). Although the conduit transported extensive sand basinward, the intraslope segment of the channel was dominated by sediment bypass (modified from Hubbard et al. 2010).D, E) Sandstone-filled trace fossils of the Cerro Toro Formation, which subtend from erosion surfaces found within slope strata. In each case the trace fossils 
of sediment bypass at the system-scale (10s to $100 \mathrm{~s} \mathrm{~km}$ ) (Gardner et al. 2003; Fildani et al. 2009; Flint et al. 2011; van der Merwe et al. 2014). A series of high-relief clinoforms that crop out in the Magallanes Basin of southern Chile preserve segments of slopes that were at least $30-40 \mathrm{~km}$ long, from the shelf edge to the lower slope (Fig. 7G, H, I) (Romans et al. 2009; Hubbard et al. 2010). Evidence for sediment bypass in upper to middle slope positions includes lags of extrabasinal clasts (Fig. 7C) and up to 8-m-thick conglomerate units that contain upstream-facing, dunescale cross-stratification (Fig. 7A). These deposits, prevalent in composite 20-60 m thick siltstone-dominated sedimentary packages that also include isolated sandstone bodies, can be tracked basinward, where they pass into stacked sandstone-dominated channel complexes that comprise $300 \mathrm{~m}$ of stratigraphy (Hubbard et al. 2010; Macauley and Hubbard 2013). The shift from more proximal, siltstone- and conglomeratedominated slope sections that are 10 s of meters thick to distal, sandstoneprone units that are 100s of meters thick is interpreted to be the result of long-lived sediment bypass of the slope.

Slope channel-levee complexes in Sub-Unit C2 in the Fort Brown Formation, Karoo Basin, South Africa, record $>50 \mathrm{~m}$ of composite erosion with multiple erosion surfaces overlain by claystone- and siltstone-clast conglomerates (Di Celma et al. 2011; Hodgson et al. 2011; Morris et al. 2014). These channel-levee complexes are stratigraphically attached down-system to $\sim 40 \mathrm{~km}^{3}$ of sandstone-rich lobe units (Van de Merwe et al. 2014). However, in the overlying "Unit E" there are basin-floor bypass-dominated zones which generate "sand-detached" lobe architectures; these areas are characterized by thin-bedded (decimeter thick) rippled sandstones with numerous shallow scours mantled by rip-up clasts, and a top surface that includes megaflutes and evidence for remobilized sediments (van der Merwe et al. 2014). These basin-floor bypass zones are related down-system to $\sim 25 \mathrm{~km}^{3}$ of sand-prone lobes.

Stratigraphic context as a means to assess sediment bypass in the outcrop record must be attempted with caution, due to the twodimensional nature of exposures (Fig. 2B). Although segments of sediment-routing systems might be correlated, longitudinally or acrossstrike, with confidence, a quantitative assessment of basin-scale down-dip sediment transfer is rarely possible.

\section{EXPRESSION OF BYPASS IN SUBSURFACE DATA}

Subsurface data, such as core, wireline logs, and seismic, can help address the spatial and stratigraphic limitations encountered by outcrop and modern seafloor datasets (Fig. 2). However, recognizing deep-water sediment bypass is challenging in subsurface datasets because the sedimentological and stratigraphic record can be subtle, and the data are typically of limited vertical and lateral resolution. In this section, a number of subsurface examples are used to illustrate the expression of deep-water sediment bypass in each of these data types; behind-outcrop boreholes and wireline logs, isolated core and wireline datasets, and seismic reflection profiles (Fig. 2C; Core 1). Finally we present a seismic reflection profile integrated with core (cuttings) and wireline data to illustrate how these complementary data can be used to interpret sediment bypass in the subsurface.

\section{Core and Wireline Logs}

Behind-outcrop research boreholes help to constrain stratigraphic successions and sedimentary facies observed in outcrop, providing an important link between subsurface data and field-based observations (Van Wagoner et al. 1990; Beaubouef et al. 1999; Donselaar and Schmidt 2005; Pickering and Corregidor 2005; Luthi et al. 2006; Luthi and Flint 2014). Where behind-outcrop cores penetrate submarine channel fills and basin-floor deposits, sedimentological processes can be deduced, and recognition criteria for sediment bypass can be grounded in $2 \mathrm{D}$ and $3 \mathrm{D}$ observations from the outcrop belt. These data are invaluable for interpretation of sediment bypass in subsurface datasets that are not characterized by outcrop or reservoir-scale 3D constraints (i.e., that which typically falls below seismic resolution).

The potential for using strategically positioned behind-outcrop boreholes to constrain the depositional record of sediment bypass is realized from analysis of the Permian Upper Brushy Canyon Formation, West Texas (Fig. 8). In this study, a detailed correlation panel built from closely spaced measured sections was constructed to constrain the depositional architecture of a lower-slope channel-complex fill at the "Buena Vista" outcrop (Fig. 8C) (Beaubouef et al. 1999). ExxonMobil EPR drilled a pair of wells behind the outcrop in the late 1990s. At outcrop, stacked channel-margin deposits are characterized by thinly interbedded fine-grained sandstone and siltstone, as well as lenses of coarse-grained sandstone that overlie multiple inclined erosional surfaces (Fig. 8D). Research borehole Buena Vista 1 (EPR BV\#1) intersected these channel-margin deposits (Fig. 8A, B) (Rossen and Beaubouef 2008). The facies association found in the core is dominated by inclined thinbedded fine- and coarse-grained turbidite sandstone and siltstone with rare debrites. Characteristically, the dip of thin beds shallow upward, but these trends are truncated by steeply inclined erosion surfaces overlain by steeply dipping beds (Fig. 8B, between y and z). The change in bed dip, the number of erosion surfaces, and the coarse-grained facies found in this thin-bedded association is interpreted to record largely bypassing flows transporting most of their sediment load basinward; the head and body of the flows bypassing all but their coarsest material and deposition of fines occurring from their tails (Beaubouef et al. 1999; Gardner et al. 2003; Rossen and Beaubouef 2008).

Criteria for sediment bypass can be established in cores that are isolated from nearby outcrop. The presence of erosion surfaces can be used to interpret channel incision and bypass-dominated intervals. These surfaces may be overlain by lag deposits of intraformational or extrabasinal clast-rich conglomerate (Fig. 9A) (Beaubouef et al. 1999; Pickering et al. 2001; Pickering and Corregidor 2005; Luthi et al. 2006; Mayall et al. 2006; Hubbard et al. 2009; Grundvag et al. 2014), or draped by fine-grained sandstone and mudstone (Fig. 9B). Identification of erosion surfaces across the diameter of a core can be challenging (e.g., Fig. 9B). Therefore, particular facies associations can be used to infer the

\section{$\leftarrow$}

penetrate muddy debrites, and indicate that turbulent flows transporting sand passed across the overlying sediment-water interface. Passively filled trace fossils are indicated with white arrows.F) Thinly interbedded sandstone and mudstone within a slope channel or scour fill in the Ardath Formation, coastal California. The incision was associated with erosive flows that likely bypassed much of their sediment basinward.G) Eastward view of an outcropping high-relief basin margin in satellite imagery draped on topography, along the Chile-Argentina border, Magallanes Basin. The north-south oriented transect is $40 \mathrm{~km}$ long, with units at the top (east) of the image fluvial-deltaic in origin, and those towards the base (west) dominated by sediment-gravity-flow deposits.H) A line-drawing trace of the area outlined by the white dashed rectangle shown in Part G. Sandstone-dominated nonmarine to shallow-marine strata are detached from deep-water, lower-slope sandstone units as a consequence of bypass of coarse-grained sediment in upper-slope to middle-slope settings.I) Idealized highly vertically exaggerated depositional-dip cross section through clinoform-dominated strata showing detached shelf and deep-water sandstone units. Numbers 1, 2, and 3 delineate successive clinothems, as in images G and $\mathrm{H}$. 


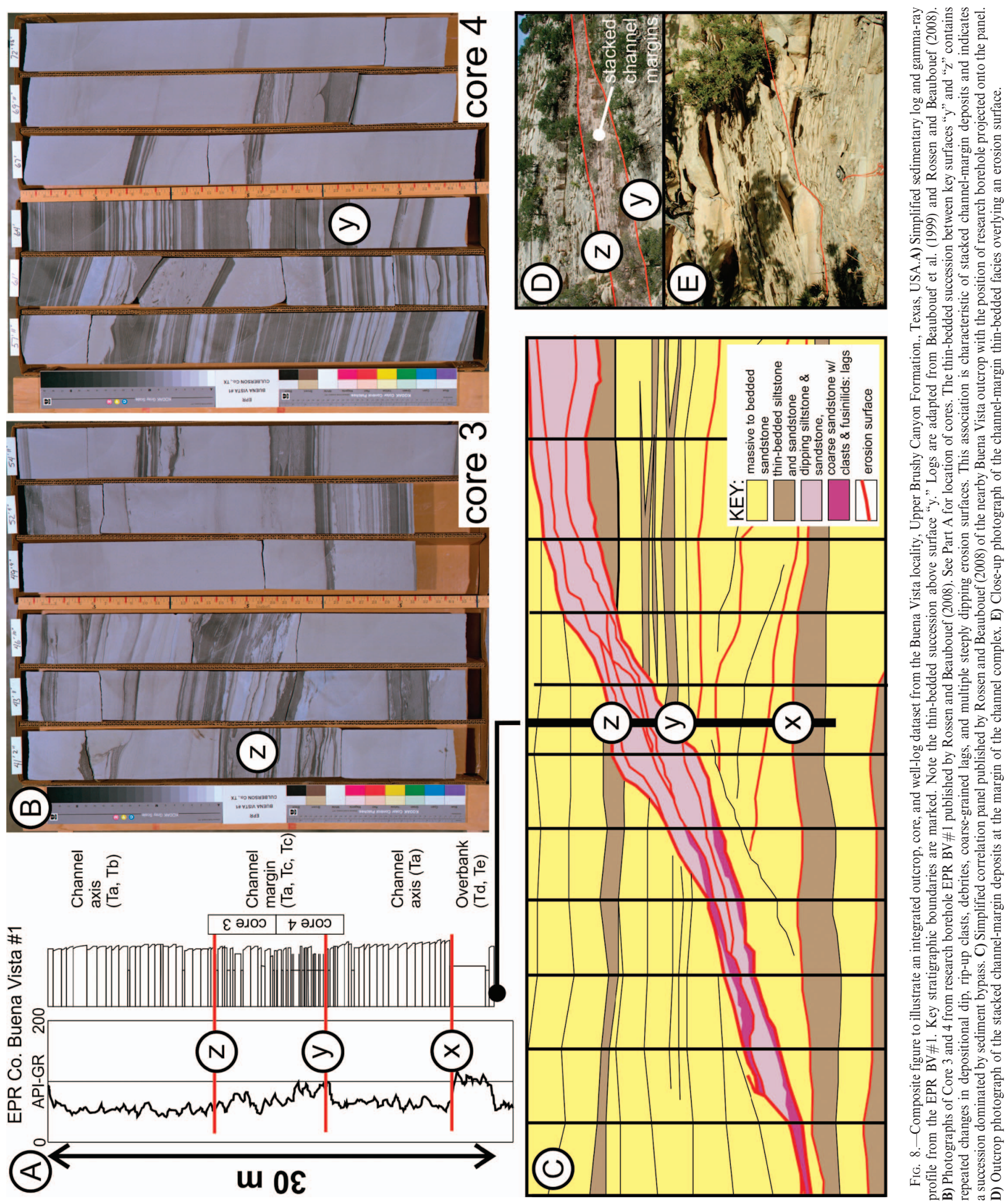



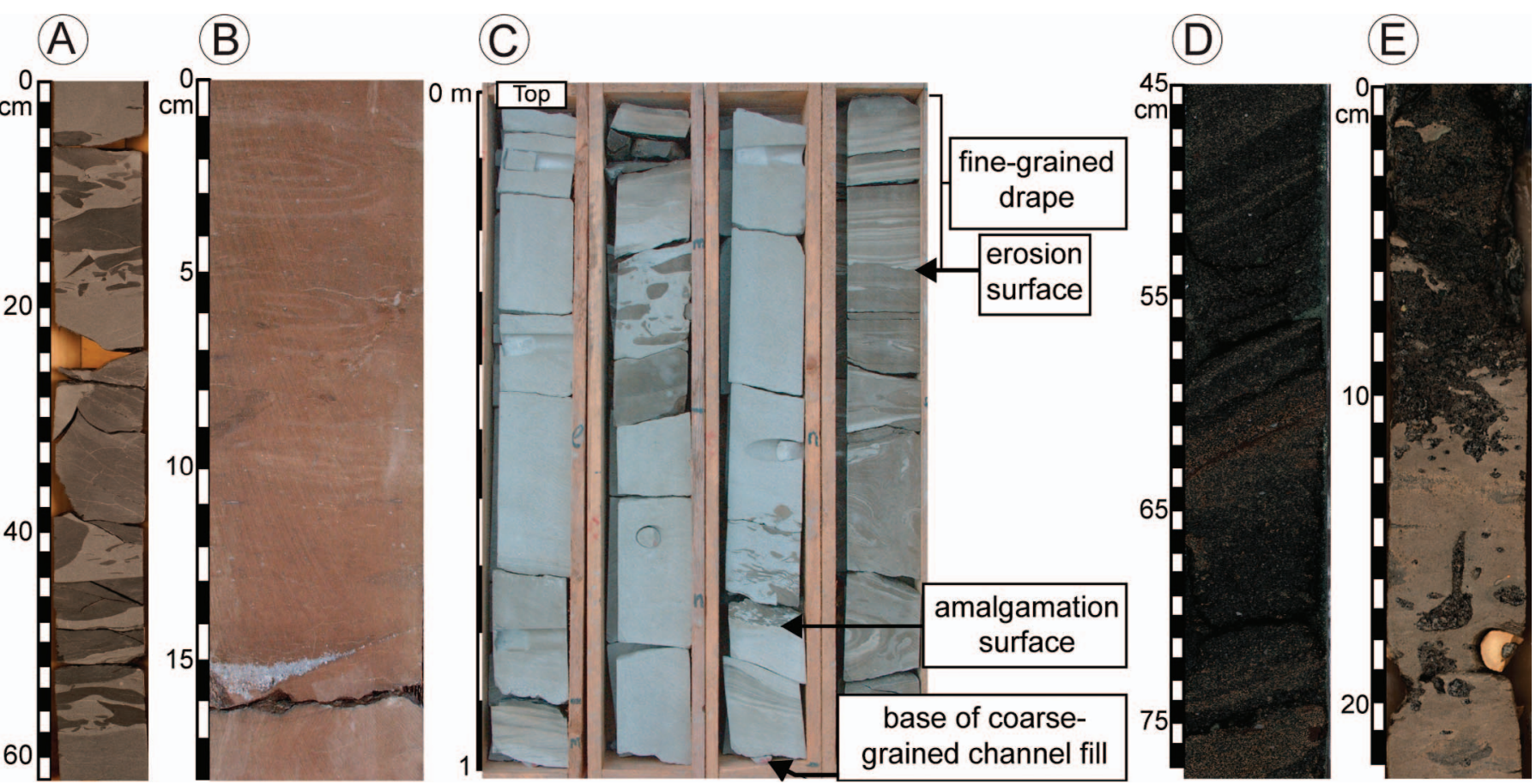

FIG. 9.-Representative photographs of indicators of sediment bypass in core. A) Claystone and siltstone clasts in a fine-grained sandstone matrix from BAV1a research borehole cored behind the C/D ridge through sub-unit C2, Fort Brown Formation, Karoo Basin, South Africa, interval from $200.77 \mathrm{~m}$ (see Morris et al. 2014 for location). B) Thin coarse-grained lag draping an erosion surface, in turn overlain by fine silt and mud, Upper Puchkrichen Formation, Austria (adapted from Hubbard et al. 2009). C) Interpreted channel-fill succession with an erosion surface draped by fine-grained beds overlain by progressively thicker sandstones, Upper Puchkrichen Formation, Austria. D) Moderately sorted cross-bedded glauconitic medium sand with clay-rich interlamination deposited at the base of a clinothem. Heterolithic laminae suggest that the bedform migrated episodically, and is therefore indicative of sediment bypass. Note apparent steepening-upward trend in dip of cross beds as characteristic of the dune-scale bedform. From IODP Expedition 313, offshore New Jersey, core 313-M0028A-118R-1. E) Sharp erosional contact at $11 \mathrm{~cm}$ between dark brown sand (above) and pale brown silty clay (below). Coarse-sand infilled Thalassinoides burrows that subtend from the erosional surface into the underlying silty clay. This is interpreted as indicating open burrows in firmground with bypass-dominated flows depositing coarse-grained lags that infill the exhumed burrows. From IODP Expedition 313, offshore New Jersey, core 313-M0029A-208R-1.

base of a channel and its overlying fill. For example, an erosion surface draped by thin-bedded fine-grained sandstone and mudstone may record the base of a channel fill (Fig. 9C). In this case, the thin beds are attributed to periods of erosion and sediment bypass, as are the overlying structureless sandstone beds with abundant rounded mudstone clasts at their base (Fig. 9C).

Dune-scale cross-bedding intercalated with mudstone drapes and coarse-grained filled trace fossils can also be observed in drill cores (Fig. 9D, E). As in outcrop, these facies can be interpreted to record sediment bypass. The interpretation of sediment bypass from cores recovered from offshore New Jersey (IODP Expedition 313) is supported by reflection seismic data that show that the succession is located at the base of slope, with stratigraphically equivalent thicker sandy turbidites encountered in another core drilled approximately $10 \mathrm{~km}$ down-system (Miller et al. 2013).

\section{Seismic Expression of Deep-Water Sediment Bypass}

Seismic reflection data represent a powerful tool with which to investigate the architecture and evolution of deep-water sedimentary systems (e.g., Posamentier and Kolla 2003; Deptuck et al. 2003, 2007; Wynn et al. 2007; Janocko et al. 2013; Ortiz-Karpf et al. 2015). However, a key constraint on the application of these data is their finite vertical and lateral resolution to image a geological feature. Due to increasing velocity and frequency attenuation with depth, seismic resolution decreases (e.g., Brown 2011). At a given depth, vertical seismic resolution has two components: separability and visibility. The limit of separability is the thickness at which reflections from two successive interfaces begin to interfere; typically $1 / 4$ of the dominant wavelength (Widess 1973). The limit of visibility is the minimum thickness at which the reflections from two successive interfaces can be seen; typically $1 / 30$ of the dominant wavelength, depending on the signal-to-noise ratio and the impedance contrast at the interfaces (Brown 2011). These limitations in vertical resolution impact our ability to identify stratigraphic surfaces and units associated with deep-water sediment bypass. For example, a sandstonemantled erosion surface, which is encased in an otherwise mudstonedominated succession (e.g., slope-channel coarse-grained lags; Fig. 7A) may not be expressed geometrically (i.e., as an erosion surface truncating underlying reflections) or acoustically (i.e., as a change in seismic amplitude) if the sandstone is too thin or if the contrast in acoustic impedance between the sandstone and mudstone is too small. Only if the sandstone is sufficiently thick will it be expressed via a change in amplitude, and may coincide with an erosion surface truncating underlying reflections (provided that the magnitude of incision is within resolution).

To illustrate the variable and subtle expression of deep-water sediment bypass in seismic reflection datasets we use examples from offshore Colombia and Brazil. The time-migrated 3D dataset collected in 2009, offshore Colombia, has an inline and crossline spacing of $12.5 \mathrm{~m}$, a dominant frequency of $30 \mathrm{~Hz}$, and a vertical and horizontal resolution of approximately $15 \mathrm{~m}$. Figure 10 shows a composite channel-form body, approximately $1.3 \mathrm{~km}$ wide and $300 \mathrm{~m}$ thick, incised into a packages of low-amplitude, shallow-dipping reflectors that taper away from the channel form (marked 1). The base of the channel form is expressed as a composite surface that comprises multiple incisions (marked 2). Within 

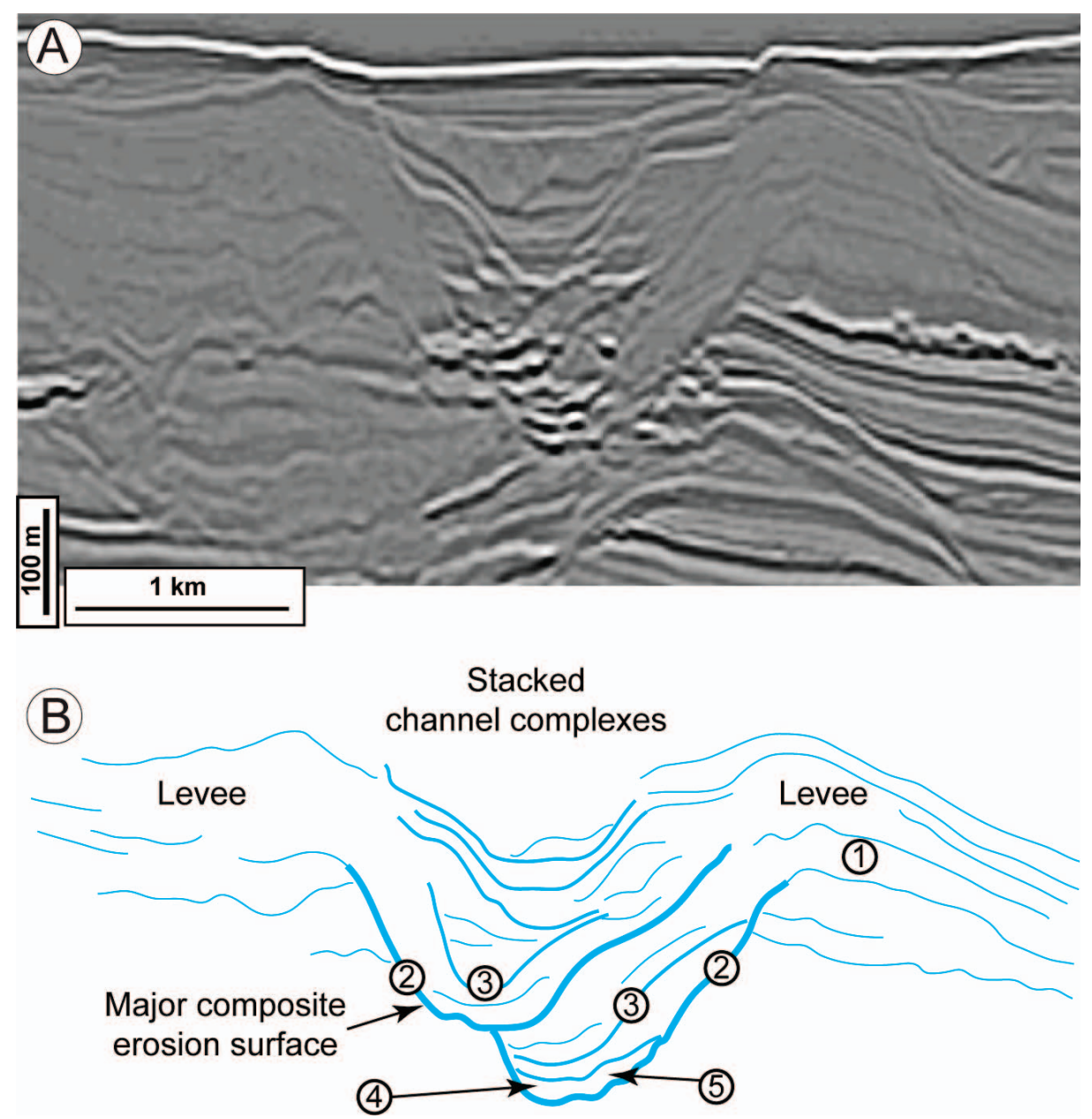

FIG. 10.-A) Seismic reflection profile and B) interpretation, from offshore Colombia, showing a composite channel-form body. External levees ("1") are incised by a major composite erosional surface ("2") 100s m deep. Internal to this surface are smaller-scale incisional channel forms that are laterally offset (" 3 "). The bases of these channel forms contain high- and low-amplitude reflectors ("4" and " 5 "), interpreted as representing coarse-grained basal lags and internal levee deposits respectively. The composite nature of the erosion surfaces, the presence of lag deposits and internal levees, coupled with the disparity in thickness between the thick external levees and thinner channel fill, suggests that the channel form represents repeated and long-lived sediment bypass. this there are a number of smaller-scale, laterally offset channel forms, approximately 200-500 m wide and up to $80 \mathrm{~m}$ thick (marked 3 ). The seismic facies characterizing the basal parts of the channel forms vary laterally. For example, high-amplitude reflections may be present on one side of the channel forms (marked 4) whereas low-amplitude reflections occur on the other (marked 5).

Similar composite channel-form bodies are widely observed in subsurface datasets (e.g., Deptuck et al. 2003, 2007; Mayall et al. 2006;

W

$\mathrm{E}$

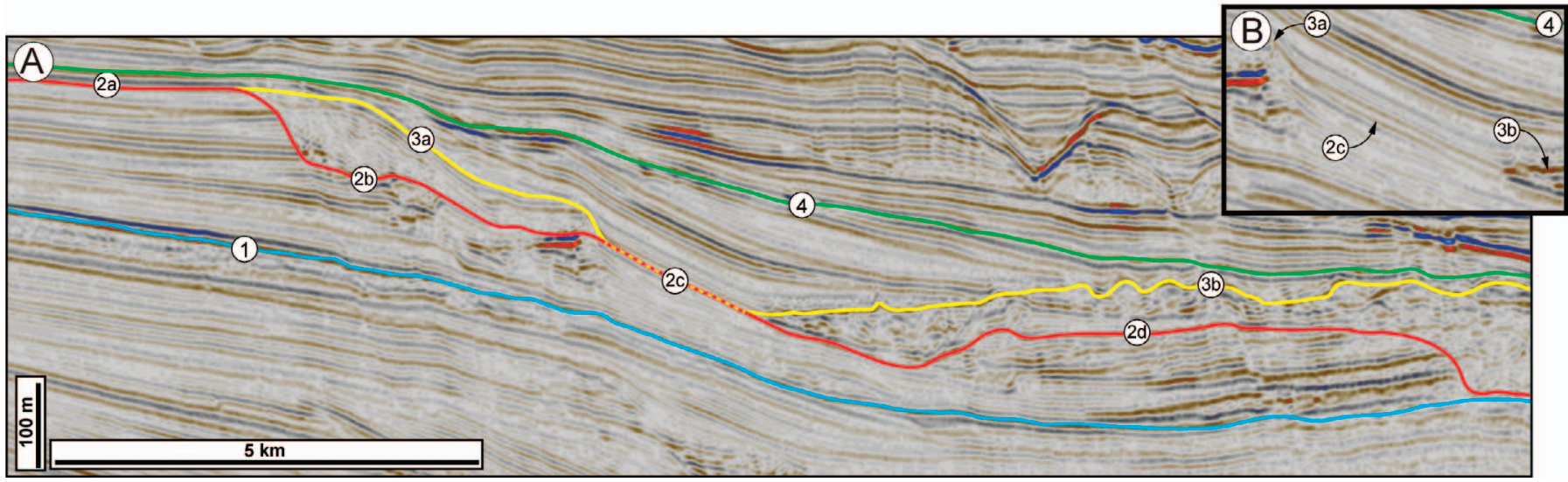

Fig. 11.-A) Seismic reflection profile from offshore Brazil showing the seismic expression of sediment bypass. Reflection 1 (blue) represents a notional basal datum. Reflection 2 (red) is composed of four genetically related segments; 2a) conformable on-shelf reflection; 2b) base of outer-shelf and upper-slope collapse scar; 2c) cryptic sediment bypass surface; 2d) base of MTD derived from outer-shelf and upper-slope collapse. Reflection 3 (yellow) is composed of two segments; 3a) top of clinoform succession that "heals" outer-shelf and upper-slope scar (see Nemec et al. 1990); 3b) top of MTD derived from outer-shelf and upper-slope collapse. Reflection 4 (green) represents a notional upper datum and defines the top of the clinoform-bearing succession in this part of the basin. B) A zoom-in of the cryptic sediment bypass surface " $2 \mathrm{c}$ " without interpreted lines, which illustrates the subtle expression of the sediment bypass surface. 

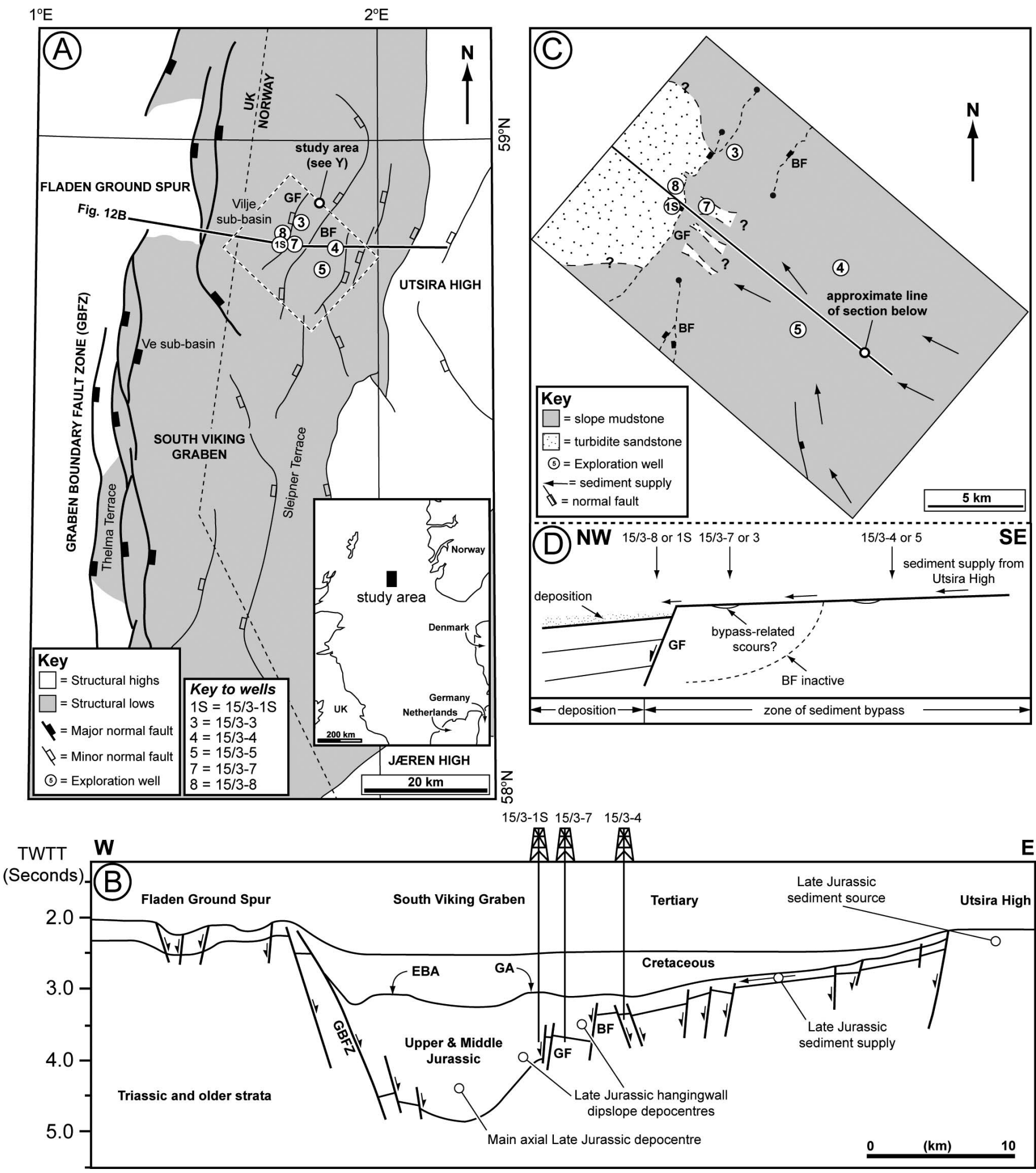

Fig. 12.-A) Simplified map illustrating the structural setting of, and structural terminology for, the South Viking Graben, offshore Norway (adapted from Jackson et al. 2011). Only the main extensional faults related to the Late Jurassic rift event are shown for clarity. Inset map shows the geographic location of the study area. The locations of the study area and Upper Jurassic paleogeographic map shown in Part C), and the geoseismic section shown in Part B are indicated (Modified from Thomas and Coward 1996; Jackson et al. 2011). B) Simplified geoseismic section across the South Viking Graben illustrating the main structural features and their spatial relationships. See Part A for location of section. The main structures of interest here are the Gudrun Fault (GF) and the Brynhild Fault (BF). C) Paleogeographic map and D) cross section for the late Oxfordian (156-154.2 Ma) interval (Units A and B; see stratigraphic correlation shown in Fig. 13). The approximate location of Part D is shown in Part C. 


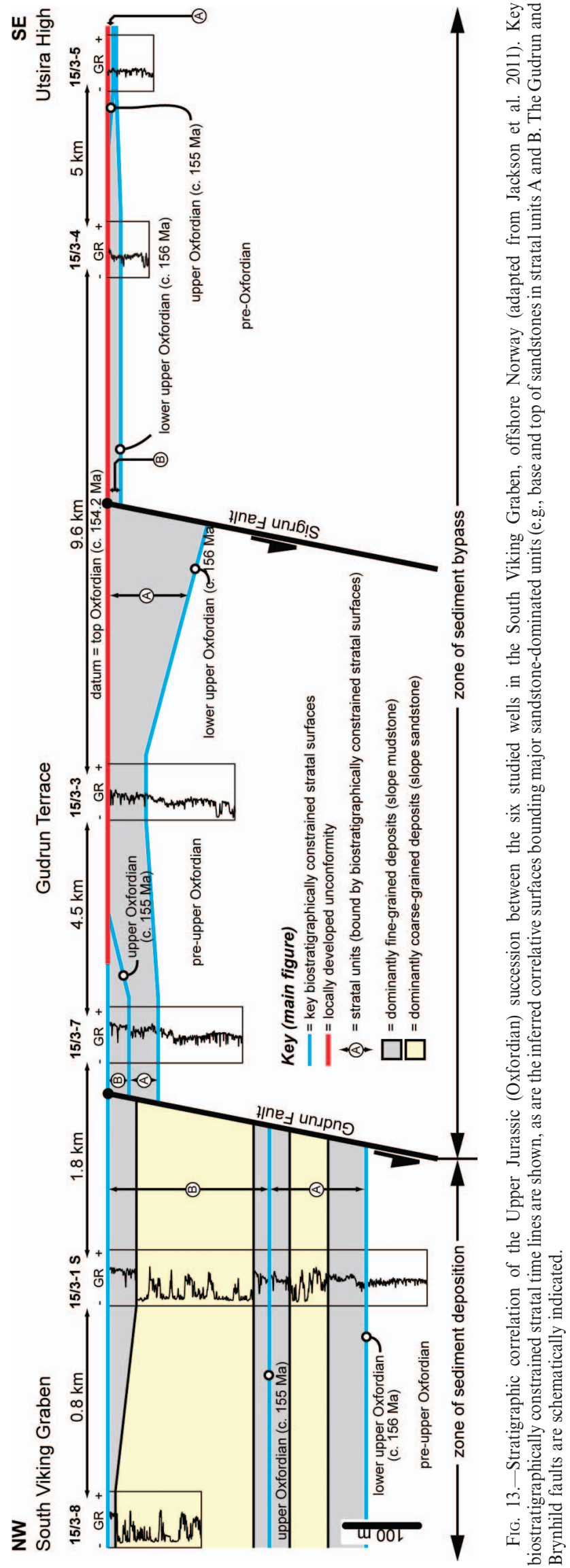

Janocko et al. 2013; Ortiz-Karpf et al. 2015). In particular, Deptuck et al. (2003) used 3D reflection seismic data to propose a link between processes and sedimentary products during protracted channelization on continental margins. In their conceptual model, long-lived and multiphased incision establishes the template for the subsequent focus of channels, and initiates external levee growth. Initial sinuous channels are laterally offset and are highly erosional, the flows cannibalizing early deposits and transferring the exhumed sediment downslope. Subsequent establishment of internal levees promotes channel aggradation, and the final product preserved in the rock record includes a composite, time transgressive, confining surface kilometers wide and hundreds of meters deep (cf. Strong and Paola 2008; Sylvester et al. 2011). Internal to this large-scale feature are smaller-scale channel forms 200-1000 m wide and up to $100 \mathrm{~m}$ thick (aspect ratios $=10-20$ ). Linking observations from outcrop, described earlier, with the larger-scale subsurface architecture supports an interpretation that these subsurface channel forms represent long-lived and multi-phased incision associated with large amounts of sediment bypass.

The time-migrated 3D seismic reflection dataset, collected offshore Brazil, has an inline and crossline spacing of $25 \mathrm{~m}$ and $12.5 \mathrm{~m}$ respectively, and a vertical sample spacing of $4 \mathrm{~ms}$. Vertical and horizontal resolution are estimated to be $20 \mathrm{~m}$. In the profile shown in Figure 11, a series of flat-lying, subparallel reflections in the west (marked 2a) are truncated by a concave-up, east-facing erosional surface (marked 2b) that is downlapped by clinoforms (marked 3a). In the central part of the profile a series of relatively conformable, gently eastward-dipping clinoforms are observed, which show limited variations in amplitude (marked 4). Down dip of this point, a package of relatively chaotic, variable-amplitude reflections is developed, which has a highly rugose upper surface (marked $3 \mathrm{~b}$ ) and which onlaps and pinches out westward onto a discrete clinoform surface developed in the clinoformbearing succession. Clinoforms downlap the concave-upward surface in the western part of the profile and the underlying package of chaotic reflections in the east (marked 4).

The observed seismic-stratigraphic architecture is interpreted to document the progradation, collapse, and reestablishment of a shelf margin (cf. Nemec et al. 1988; Dixon et al. 2013). The concave-upward surface (2b) represents the shelf-edge failure scar (cf. Levell and Kasumajaya 1985), which truncates flat-lying shelf strata (e.g., 2a). The clinoforms that downlap this surface (e.g., 3a) record healing of relief associated with scar formation. The chaotic package of reflections (overlying surface $3 \mathrm{~b}$ ) developed down-system at the toe of slope is interpreted as a mass-transport deposit (MTD), sourced from the failure of the shelf edge. The size of the shelf-edge scar and the volume of the MTD together indicate that a significant amount of material was remobilized from the shelf edge during this event. A critical question is therefore: What is the seismic expression of the stratigraphic surface that documents this major slope bypass event?

Based purely on seismic-stratigraphic relationships, in particular (i) the location of MTD pinchout on the lower slope and (ii) the lower slope position of the stratigraphic surface downlapped by shelf-edge clinoforms, we suggest that the surface that records the major slope bypass event is located on the lower slope, between the horizons that define the top and base of the failure scar up-system, and the top and base of the MTD down-system (marked 2c in Fig. 11). This interpretation suggests that the sediment bypass surface is extremely subtle and is represented by neither a pronounced erosional surface nor a change in amplitude (Fig. 11B). Outcrop and core data, such as those described in previous sections, suggest that it is likely that a series of incisions are developed on sediment bypass surfaces (e.g., Figs. 5A, 6A, 8). However, if present in the Santos Basin example, these features are less than a few tens of meters deep and are therefore too subtle to be imaged on these data. 


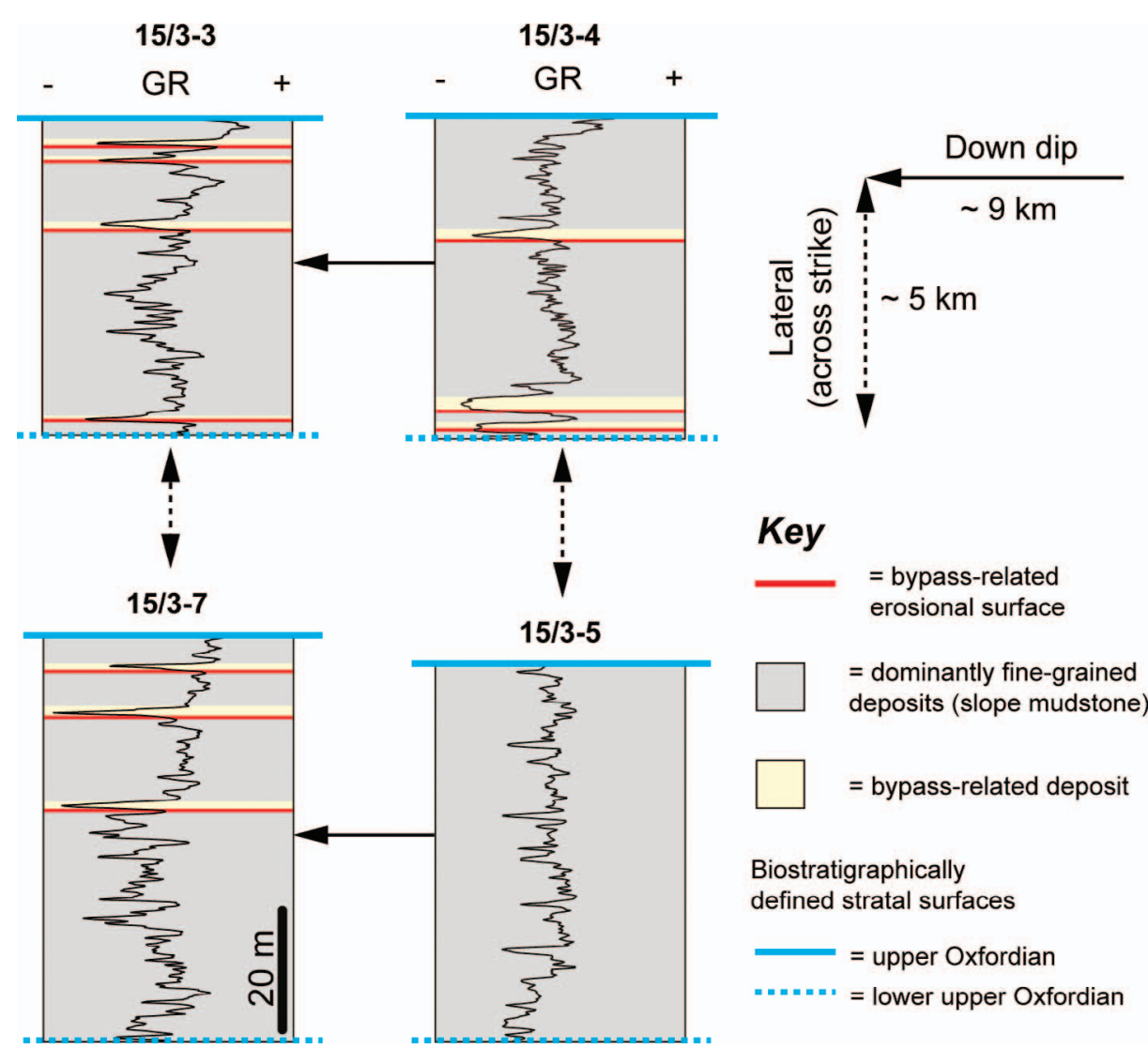

FIG. 14.-Extracts of wireline log data (GR) from wells located up dip of the Gudrun Field (See Fig. 11 for stratigraphic context, Fig. 10A for geographical location, and Fig. 10B for paleogeographic context of wells). The wells are located in an area inferred to have been dominated by deep-water sandstone bypass. Lower-value GR spikes suggest the presence of thin $(<2 \mathrm{~m})$, sharp-based sandstones developed in an otherwise fine-grained succession. Cuttings data in stratal unit B in 15/3-7 confirm this inference, documenting "stringers of fine to very coarse sandstone." See text for discussion.

\section{Expression of Sediment Bypass in Integrated Core, Wireline, and Seismic Data}

Identification of sediment bypass surfaces in seismic datasets can be augmented by cores and well logs. To highlight this we draw on an example from the Upper Jurassic of the South Viking Graben, northern North Sea (Fig. 12A) (Jackson et al. 2011). In this location, deposition of syn-rift turbidite sandstone and slope mudstone was synchronous with activity on a series of thin-skinned, gravity-driven normal faults (Fig. 12B) (Thomas and Coward 1996). The upper Oxfordian turbiditebearing succession displays large and abrupt changes in thickness across a seaward-dipping fault (the Gudrun Fault; Fig. 13). Well data indicate that $80-200 \mathrm{~m}$ thick sandstone-rich packages are developed in the hanging wall of the fault with intervals of amalgamated sandstones up to $40 \mathrm{~m}$ thick (Fig. 12; 15/3-1S and 15/3-8). In contrast, well data (15/3-7) from the footwall indicate that the equivalent succession is relatively thin $(<50 \mathrm{~m})$ and mudstone-dominated, indicating that the thick, sandstonerich, turbidite-dominated part of the upper Oxfordian succession is restricted to the hanging wall of the Gudrun Fault. This observation prompts the question: What is the sedimentological record of sediment bypass up-system of the thick sandstone packages? Detailed analysis of closely spaced $(<0.2 \mathrm{~m})$ cuttings data in the footwall well $(15 / 3-7)$ indicate that a number of thin $(1-2 \mathrm{~cm})$, sharp-based, very-fine to medium-grained sandstones are developed in the footwall of the Gudrun Fault, and that these are age-equivalent to the upper Oxfordian turbiditedominated packages identified $1.8 \mathrm{~km}$ farther down-system. Furthermore, close inspection of wireline logs up-system of the hanging wall indicate that, despite an overall high gamma radioactivity (generally $>$ $120 \mathrm{API})$, the succession in the footwall contains a number of low GR $(<$ 80 API) "spikes," which correspond to the sandstones documented in cuttings data (Fig. 14). These thin sandstones are interpreted as lag-type units deposited beneath partially bypassing sand-rich flows, similar to facies described previously in modern seafloor (e.g., Fig. 5A), outcrop (e.g., 7C), and core (Figs. 8, 9A). This record of sediment bypass is variable both down-system and across-strike with low GR $(<80$ API) "spikes" not recorded in well 15/3-5 (located $4.5 \mathrm{~km}$ from 15/3-7) (Fig. 14).

\section{DISCUSSION}

\section{What is the Spatial Variability in the Stratigraphic Expression of Sediment Bypass?}

The case studies outlined in this paper illustrate the spectrum of recognition criteria that can be used to interpret sediment bypass in deepwater systems. These sediment bypass indicators vary spatially, across different parts of deep-water systems. In this section we place the range of sediment bypass indicators into assemblages found in different positions down the profile of an idealized deep-water system. This multi-scale synthesis of sediment bypass criteria complements gross-scale analysis of sediment bypass, derived from seismic profiles (Paola and Martin 2012).

Slope-Channel Bypass.-Slope-channel settings in modern seafloor, outcrop, and subsurface datasets have a range of features indicative of sediment bypass (Fig. 15A). These include: 1) abundant composite erosion surfaces (e.g., Figs. 6A, B, 8C, 10) that are often draped by thin-bedded sandstone and mudstone, preferentially preserved towards channel margins (Figs. 6C, D, E, 8D, E, 9C); 2) sandstone-filled trace fossils that subtend from the bases of mudstone-filled channel-forms (Figs. 7D, E, 9E); 3) lenticular coarse-grained lag deposits ranging in thickness from centimeters to meters thick, which may be characterized by large-scale cross stratification (Figs. 7A, B, 9D); and 4) external levees, which form a laterally equivalent depositional record of sediment bypass within the channel axis (e.g., Fig. 10A). 

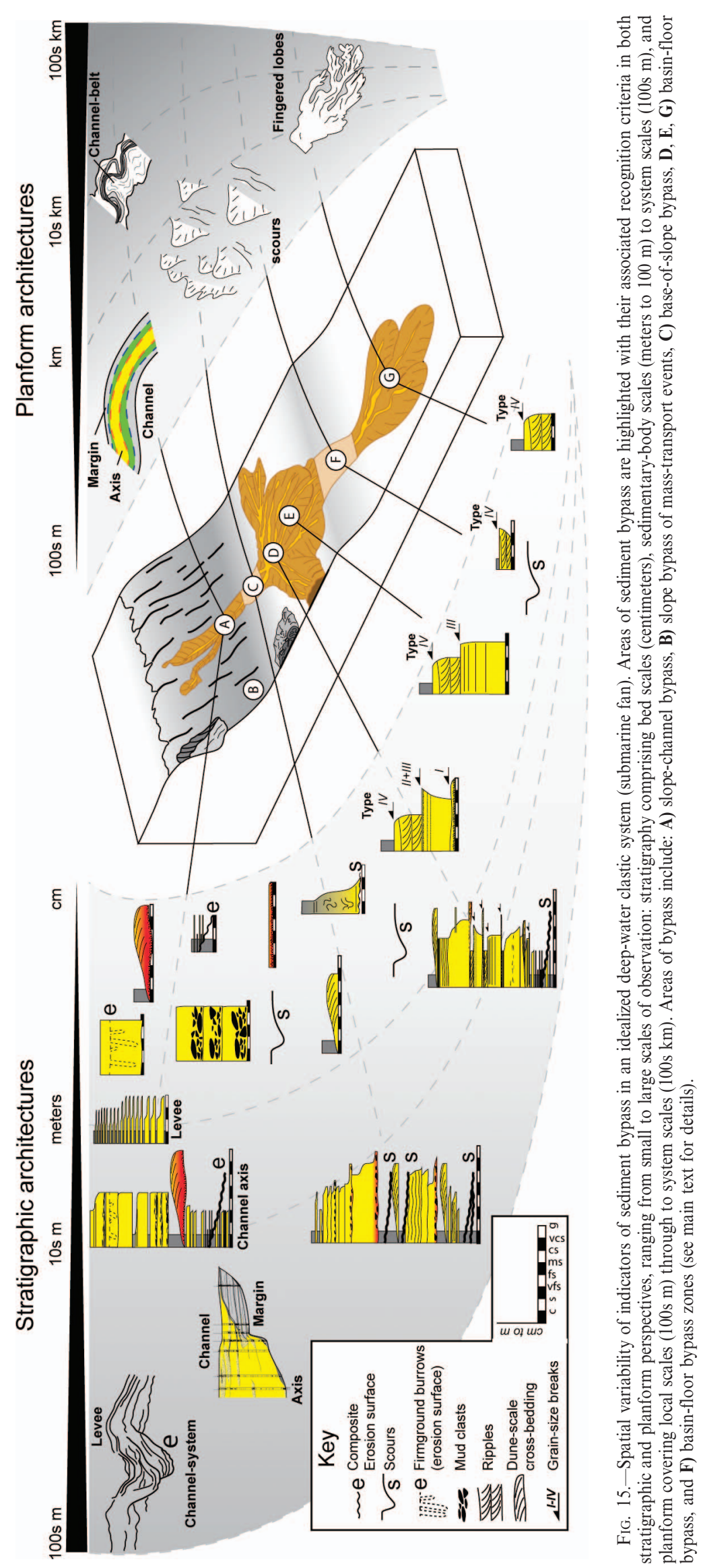
Slope Bypass from Mass-Wasting Events.-In outcrop and subsurface, striations at the base of MTDs may aid identification of the sediment bypass surface and the direction of sediment transport (e.g., Pickering and Corregidor 2005; Moscardelli et al. 2006; Dakin et al. 2013; Olafiranye et al. 2013; Ortiz-Karpf et al. 2015). Where the sediment bypass surface is not directly overlain by its genetically related MTD, identifying the surface is challenging. At outcrop and in core, this surface may be cryptic and it may only be possible to infer its presence based on the recognition of high-angle truncation surfaces (erosional cuts) or an abrupt vertical change in facies (e.g., Beaubouef et al. 1999; Brunt and McCaffrey 2007; Rossen and Beaubouef 2008; Di Celma et al. 2011; Macauley and Hubbard 2013). In seismic reflection datasets, MTDrelated bypass surfaces can be extremely subtle and challenging to detect (Fig. 11B). Such cryptic sediment bypass surfaces may only be identifiable based on their wider spatial context, such as its location between an upslope slide scar and a downslope MTD (Figs. 11A, 15B).

Base-of-Slope (CLTZ) Bypass.-Several sediment bypass indicators recorded in base-of-slope settings are also found in slope-channel settings (Fig. 15C). It is possible that base-of-slope settings, which are spatially coincident with CLTZs, may have well-developed channels (e.g., van der Merwe et al. 2014), making it difficult to compartmentalize slope-channel and base-of-slope settings based on isolated indicators of sediment bypass. Indicators of sediment bypass in base-of-slope (CLTZ) settings (Fig. 15C) include: 1) isolated and amalgamated scours 10's m deep and kilometers in areal extent, which are typically overlain by fine-grained thin-bedded drapes (Fig. 5A); 2) where scouring is absent, thin (centimeter to decimeter), coarse-grained sand and conglomeratic lags, often with lenticular bed geometries (e.g., Figs. 5A, 9A); and 3) rarely, lenticular coarse-grained sandstones with dune-scale cross bedding (Fig. 9D). The similarities in facies associations between slope-channel and base-of-slope settings mean that a wider, regional, context is required to distinguish them, and their associated bypass criteria.

Basin-Floor Bypass.-Indicators of sediment bypass in basin-floor environments are expressed internally within beds as grain-size breaks (e.g., Fig. 5). Grain-size breaks are most common in proximal localities and become progressively less frequent with distance from source (Fig. 15D, E, G). Basin-floor settings may have relatively distal bypassdominated zones, where the system changes longitudinally from depositional to bypass-dominated (Fig. 15F). Bypass indicators across these zones include inversely graded rippled sandstones with sharp tops and almost no mud caps (Fig. 5B), and shallow (decimeter) isolated scours (van der Merwe et al. 2014). Certain areas (down-system and laterally) may also be subject to complete sediment bypass, whereby flows leave no trace of their passing.

Similar criteria for sediment bypass can be found in more proximal settings such as slope channels and base-of-slope settings. However, a number of important differences exist at a bed and sedimentary-body scale, which may allow them to be distinguished. First, all of the sandy deposits in a basin-floor bypass-dominated zone will be relatively finegrained compared to more proximal localities. Second, scouring in basinfloor bypass-dominated zones is more likely to be isolated (van der Merwe et al. 2014), which contrasts with the composite erosion surfaces found proximally. From a wider stratigraphic perspective, basin-floor sheet sands or lobes (e.g., Hodgson et al. 2006; Amy and Talling 2006; Talling et al. 2007; Prélat et al. 2009) should be found both up-system and down-system of the basin-floor bypass zone (e.g., Stevenson et al. 2013; van der Merwe et al. 2014).

\section{Using Theoretical and Numerical Frameworks as Predictive Tools}

Theoretical and numerical criteria struggle to predict sediment bypass across a range of experimental flow conditions. Equations 1-8 assume that turbulence maintains sediment in suspension. This assumption breaks down at higher sediment concentrations, where turbulence is suppressed and grains are transported in the flow via other mechanisms, such as hindered settling and grain-to-grain collisions (Lowe 1982; Postma et al. 1988; Sohn 1997; Cartigny et al. 2013). Hence, sediment concentration can have a positive influence on the ability of flows to transport and bypass sediment (cf. van Maren et al. 2009). This phenomenon is not yet included in criteria that describe sediment bypass and may explain the limitations of the approaches outlined in this paper to predict bypass in the high-concentration experiments of Cartigny et al. (2013). In addition, the criteria do not explicitly link boundary-layer conditions with those in the upper parts of the flow. Poor validation, coupled with a limited ability to relate properties of the lower and upper parts of a flow, means that it is not possible to quantitatively link bypassing flow processes with deposits observed in the field.

The common parameters of grain size, sediment concentration, slope, and flow size, however, are linked through a physical framework, which can be applied in a qualitative sense to support conceptual models and interpretation of bypass facies in the field. For example, Mutti and Normark (1987) proposed varying styles of bypass in base-of-slope settings (CLTZs), which are controlled by flow size and grain size (two parameters highlighted above). Small-volume and coarse-grained flows have a high sensitivity to breaks in slope, whereby they deposit rapidly (low bypass), producing localized wedge or lenticular geometries. In contrast, large flows with a significant amount of fine-grained sediment have a lower sensitivity and largely bypass the break in slope. This results in bypass facies such as mud-draped scours, thin coarse-grained lags, and deposits with large-scale cross bedding (e.g., Fig. 15). Qualitatively associating these parameters (within an established physical framework) with particular styles of bypass and facies in the field is an important step towards quantitatively linking process with product in deep-water systems.

\section{CONCLUSIONS}

This contribution examines the phenomenon of sediment bypass in deep-water clastic systems from the key physical processes that govern it to the expression left behind in the stratigraphic record.

At the temporal and spatial scale of individual flows, bypass is governed by vertical and longitudinal variations in flow dynamics, which evolve with distance down-system. From a range of theoretical and numerical approaches we outline the principal controls that underpin these dynamics, which in turn govern sediment bypass: grain size, slope, flow size, and sediment concentration. However, these approaches struggle to predict bypassing flow conditions across a range of physical experiments. Poor validation through experiments and a paucity of direct measurements from natural flows (cf. Talling et al. 2015) for comparison means that it is not yet possible to establish quantitative links between deposits in the field and bypassing flow processes. This provides us with inspiration for future work connecting the processes and products of deep-water sediment bypass.

We examined the stratigraphic expression of sediment bypass in modern seafloor, outcrop, and subsurface datasets. Commonalities are found, giving rise to a spectrum of criteria that can be employed to interpret sediment bypass from the geological record at specific locations on the slope-to-basin-floor profile (Fig. 15). These criteria for sediment bypass vary spatially, from proximal to distal and laterally from axis to margin, and with the scale of observation. No single criterion is an effective tool for interpreting sediment bypass; rather, an assemblage of indicators of sediment bypass must be used depending on the paleogeographic context within the system and the scale of observation. We emphasize that an improved understanding of sediment bypass requires a holistic approach, integrating different data types at various scales of spatial and stratigraphic resolution. 
Two studies (the Moroccan Turbidite System and Karoo Basin) in which sediment volumes can be mapped down-system of bypassdominated zones show that similar facies can represent a large range of sediment volumes bypassed. Therefore, it is not possible to quantify volumes of sediment bypassed from isolated criteria. Currently, quantitative estimates can be determined only from good paleogeographic understanding of the system, i.e., mapping of stratigraphically equivalent deposits down-system of the bypass zone.

The establishment of criteria to recognize sediment bypass at multiple scales, linked with a physical framework, is an important step for improving our understanding of submarine flow dynamics and their associated depositional architectures, and key to reducing uncertainty in the downsystem prediction of reservoir bodies in hydrocarbon exploration.

\section{ACKNOWLEDGMENTS}

We wish to thank the SEPM for sponsoring the "Sediment Bypass in DeepWater Systems" evening session at the AAPG AGM, Pittsburgh (2013), Bret Dixon for organizing the session, and the numerous scientists who contributed to an engaging and lively discussion. Brian Romans and Zoltan Sylvester are thanked for their thorough and constructive reviews, which have greatly improved the paper. Morgan Sullivan is thanked for editorial handling of the manuscript and for making additional valuable comments. We thank Andrea Ortiz-Karpf for providing the seismic reflection profile in Figure 10

\section{REFERENCES}

Amy, L.A., Kneller, B., and McCaffrey, W.D., 2000, Evaluating the links between turbidite characteristics and gross system architecture: upscaling insights from the turbidite sheet-system of the Peïra Cava, SE France: SEPM, Gulf Coast Section, 20th Annual Research Conference, Deep-Water Reservoirs of the World, p. 1-15.

Amy, L.A., McCaffrey, B., and Kneller, B., 2007, The Peïra Cava Outlier, Annot Sandstones, France, in Nilsen, T.H., Shew, R.D., Steffens, G.S., and Studlick, J., eds., Atlas of Deep-Water Outcrops: American Association of Petroleum Geologists, Studies in Geology 56, p. 185-187.

Allen, J.R.L., 1982, Chapter 10. Structures and sequences related to gravity current surges, in Sedimentary Structures: Their Character and Physical Basis, Volume 1: Amsterdam, Elsevier, p. 395-431

ARNotT, R.W.C., 2007, Stratal architecture and origin of lateral accretion deposits (LADs) and conterminuous inner-bank levee deposits in a base-of-slope sinuous channel, lower Isaac Formation (Neoproterozoic), East-Central British Columbia, Canada: Marine and Petroleum Geology, v. 24, p. 515-528.

Babonneau, N., Savoye, B., Cremer, M., and Klein, B., 2002, Morphology and architecture of the present canyon and channel system of the Zaire deep-sea fan: Marine and Petroleum Geology, v. 19, p. 445-467.

Babonneau, N., Savoye, B., Cremer, M., and Bez, M., 2010, Sedimentary architecture in meanders of a submarine channel: detailed study of the present Congo Turbidite Channel (ZAIANGO Project): Journal of Sedimentary Research, v. 80, p. 852-866.

BAGNOLD, R.A., 1966, An approach to the sediment transport problem from general physics: U.S. Geological Survey, Professional Paper 422-I, p. 1-37.

Barton, M., O'Byrne, C., Pirmez, C., Prather, B., Van der Vlugt, F., Alpak, F.O., and Sylvester, Z., 2010, Turbidite channel architecture: recognizing and quantifying the distribution of channel-base drapes using core and dipmeter data, in Poppelreiter, M., Garcia-Carballido, C., and Kraaijveld, M., eds., Dipmeter and Borehole Image Log Technology: American Association of Petroleum Geologists, Memoir 92, p. 195-210.

Beaubouef, R.T., 2004, Deep-water leveed-channel complexes of the Cerro Toro Formation, Upper Cretaceous, southern Chile: American Association of Petroleum Geologists, Bulletin, v. 88, p. 1471-1500.

Beaubouef, R.T., Rossen, C., Zelt, F.B., Sullivan, M.D., Mohrig, D.C., and Jennette, D.C., 1999, Deep-water sandstones, Brushy Canyon Formation, West Texas: American Association of Petroleum Geologists, Continuing Education Course Notes, v. 40, p. $1-50$.

Bouma, A.H., 1962, Sedimentology of some Flysch Deposits: A Graphic Approach to Facies Interpretation: Amsterdam, Elsevier, 168 p.

Brown, B.R., 2011, Interpretation of Three-Dimensional Seismic Data, Seventh Edition: American Association of Petroleum Geologists, Memoir 42, 646 p.

Brunt, R.L., and McCAFFrey, W.D., 2007, Heterogeneity of fill within an incised channel: The Oligocene Gres du Champsaur, SE France: Marine and Petroleum Geology, v. 24, p. 529-539.

Brunt, R.L., Hodgson, D.M., Flint, S.S., Pringle, J.K., Di Celma, C., Prélat, A., and Grecula, M., 2013, Confined to unconfined: anatomy of a base of slope succession, Karoo Basin, South Africa: Marine and Petroleum Geology, v. 41, p. $206-221$

BufFINGTON, E.C., 1952, Submarine "natural levees": Journal of Geology, v. 60, p. 473-479.
Callow, R.H.T., Kneller, B., Dykstra, M., and McIlroy, D., 2014, Physical, biological, geochemical and sedimentological controls on the ichnology of submarine canyon and slope channel systems: Marine and Petroleum Geology, v. 54, p. 144-166. Cantero, M.I., Balachandar, S., and Parker, G., 2009, Direct numerical simulation of stratification effects in a sediment-laden turbulent channel flow: Journal of Turbulence, v. 10, p. 1-28.

Cantero, M.I., Cantelli, A., Pirmez, C., Balachandar, S., Mohrig, D., Hickson, T.A. Yeh, T., Naruse, H., and Parker, G., 2012a, Emplacement of massive turbidites linked to extinction of turbulence in turbidity currents: Nature Geoscience, v. 5, p. 42-45.

Cantero, M.I., Shringarpure, M., and Balachandar, S., 2012b, Towards a universal criteria for turbulence suppression in dilute turbidity currents with non-cohesive sediments: Geophysical Research Letters, v. 39, L14603, 5 p.

Cantero, M., Balachandar, S., Cantelli, A., and Parker, G., 2014, A simplified approach to address turbulence modulation in turbidity currents as a response to slope breaks and loss of lateral confinement: Environmental Fluid Mechanics, v. 14, p. 371-385

Cartigny, M.J.B., Eggenhuisen, J.T., Hansen, E.W.M., and Postma, G., 2013, Concentration-dependent flow stratification in experimental high-density turbidity currents and their relevance to turbidite facies models: Journal of Sedimentary Research, v. 83, p. 1047-1065.

Cazzola, C., Fonnesu, F., Mutti, E., Rampone, G., Sonnino, M., and Vigna, B., 1981, Geometry and facies of small, fault-controlled deep-sea fan systems in a transgressive depositional setting, in Lucchi, R.F., ed., International Association of Sedimentologists, 2nd European Regional Meeting, Bologna, Excursion Guidebook, p. 7-53.

Chapin, M.A., Davies, P., Gibson, J.L., and Pettingill, H.S., 1994, Reservoir architecture of turbidite sheet sandstones in laterally extensive outcrops, Ross formation, Western Ireland, in Weimer, P., Bouma, A.H., and Perkins, B.F., eds., Submarine Fans and Turbidite Systems: Sequence Stratigraphy, Reservoir Architecture, and Production Characteristics: SEPM, Gulf Coast Section, 15th Annual Research Conference, Proceedings, p. 53-68.

Covault, J.A., Kostic, S., Paull, C.K., Ryan, H.F., and Fildani, A., 2014, Submarine channel initiation, filling and maintenance from sea-floor geomorphology and morphodynamic modelling of cyclic steps: Sedimentology, v. 61, p. 1031-1054.

Crane, W.H., and Lowe, D.R., 2008, Architecture and evolution of the Paine channel complex, Cerro Toro Formation (Upper Cretaceous), Silla Syncline, Magallanes Basin, Chile: Sedimentology, v. 55, p. 979-1009.

Curray, J.R., Emmel, F.J., and Moore, D.G., 2002, The Bengal Fan: morphology, geometry, stratigraphy, history and processes: Marine and Petroleum Geology, v. 19, p. 1191-1223.

Dakin, N., Pickering, K.T., Mohrig, D., and Bayliss, N.J., 2013, Channel-like features created by erosive submarine debris flows: field evidence from the Middle Eocene Ainsa Basin, Spanish Pyrenees: Marine and Petroleum Geology, v. 41, p. 62-71.

Damuth, J.E., and Kumar, N., 1975, Amazon Cone: morphology, sediments, age, and growth-pattern: Geological Society of America, Bulletin, v. 86, p. 863-878.

Damuth, J.E., Kolla, V., Flood, R.D., Kowsmann, R.O., Monteiro, M.C., Gorini, M.A., Palma, J.J.C., and Belderson, R.H., 1983, Distributary channel meandering and bifurcation patterns on the Amazon Deep-Sea Fan as revealed by long-range sidescan sonar (GLORIA): Geology, v. 11, p. 94-98.

Damuth, J.E., Flood, R.D., Kowsmann, R.O., Belderson, R.H., and Gorini, M.A., 1988, Anatomy and growth-pattern of Amazon deep-sea fan as revealed by long-range side-scan sonar (GLORIA) and high-resolution seismic studies: American Association of Petroleum Geologists, Bulletin, v. 72, p. 885-911.

Deptuck, M.E., Steffens, G.S., Barton, M., and Pirmez, C., 2003, Architecture and evolution of upper fan channel-belts on the Niger Delta slope and in the Arabian Sea: Marine and Petroleum Geology, v. 20, p. 649-676.

Deptuck, M.E., Sylvester, Z., Pirmez, C., and O’Byrne, C., 2007, Migrationaggradation history and 3-D seismic geomorphology of submarine channels in the Pleistocene Benin-major Canyon, western Niger Delta slope: Marine and Petroleum Geology, v. 24, p. 406-433.

Di Celma, C., Cantalamessa, G., Didaskalou, P., and Lori, P., 2010, Sedimentology, architecture, and sequence stratigraphy of coarse-grained, submarine canyon fills from the Pleistocene (Gelasian-Calabrian) of the Peri-Adriatic basin, central Italy: Marine and Petroleum Geology, v. 27, p. 1340-1365.

Di Celma, C., Brunt, R.L., Hodgson, D.M., Flint, S.S., and Kavanagh, J.P., 2011, Spatial and temporal evolution of a Permian submarine slope channel-levee system, Karoo Basin, South Africa: Journal of Sedimentary Research, v. 81, p. 579-599.

Dixon, J.F., Steel, R.J., and Olariu, C., 2013, A model for cutting and healing of deltaic mouth bars at the shelf edge: mechanism for basin-margin accretion: Journal of Sedimentary Research, v. 83, p. 284-299.

DonselaAr, M.E., and SCHMidT, J.M., 2005, Integration of outcrop and borehole image logs for high-resolution facies interpretation: example from a fluvial fan in the Ebro Basin, Spain: Sedimentology, v. 52, p. 1021-1042.

Droz, L., Rigaut, F., Cochonat, P., and Tofani, R., 1996, Morphology and recent evolution of the Zaire turbidite system (Gulf of Guinea): Geological Society of America, Bulletin, v. 108, p. 253-269.

ElliotT, T., 2000, Megaflute erosion surfaces and the initiation of turbidite channels: Geology, v. 28, p. 119-122.

Fildani, A., Normark, W.R., Kostic, S., and Parker, G., 2006, Channel formation by flow stripping: large-scale scour features along the Monterey East Channel and their relation to sediment waves: Sedimentology, v. 53, p. 1265-1287. 
Fildani, A., Hubbard, S.M., and Romans, B.W., 2009, Stratigraphic evolution of deepwater architecture: examples of controls and depositional styles from the Magallanes Basin: SEPM, Field Trip Guidebook, 73 p.

Fildani, A., Hubbard, S.M., Covault, J.A., Maier, K.L., Romans, B.W., Traer, M., and Rowland, J.C., 2013, Erosion at inception of deep-sea channels: Marine and Petroleum Geology, v. 41, p. 48-61.

Flint, S.S., Hodgson, D.M., Sprague, A.R., Brunt, R.L., van der Merwe, W.C., Figueiredo, J., Prélat, A., Box, D., Di Celma, C., and Kavanagh, J.P., 2011, Depositional architecture and sequence stratigraphy of the Karoo basin floor to shelf edge succession, Laingsburg depocentre, South Africa: Marine and Petroleum Geology, v. 28, p. 658-674

Flood, R.D., 1987, Side echoes from a sinuous fan channel obscure the structure of submarine fan channel-levee systems, Amazon Fan: Geo-Marine Letters, v. 7, p. 15-22.

Frenz, M., Wynn, R.B., Georgiopoulou, A., Bender, V.B., Hough, G., Masson, D.G., Talling, P.J., and Cronin, B.T., 2008, Provenance and pathways of late Quaternary turbidites in the deep-water Agadir Basin, northwest African margin: International Journal of Earth Sciences, v. 98, p. 721-733.

Gardner, M.H., and Borer, J.M., 2000, Submarine channel architecture along a slope to basin profile, Permian Brushy Canyon, West Texas, in Bouma A.H. and Stone, C.G., eds., Fine-Grained Turbidite Systems: American Association of Petroleum Geologists, Memoir 72 and SEPM, Special Publication 68, p. 195-215.

Gardner, M.H., Borer, J.A., Melick, J.J., Mavilla, N., Dechesne, M., and Wagerle, R.N., 2003, Stratigraphic process-response model for submarine channels and related features from studies of Permian Brushy Canyon outcrops, West Texas: Marine and Petroleum Geology, v. 20, p. 757-787.

Garrison, L., Kenyon, N., and Bouma, A., 1982, Channel systems and lobe construction in the Mississippi Fan: Geo-Marine Letters, v. 2, p. 31-39.

Gladstone, C., and Sparks, R.S.J., 2002, The significance of grain size breaks in turbidites and pyroclastic density current deposits: Journal of Sedimentary Research, v. 72 , p. $182-191$

Grecula, M., Flint, S., Potts, G., Wickens, D., and Johnson, S., 2003, Partial ponding of turbidite systems in a basin with subtle growth-fold topography: LaingsburgKaroo, South Africa: Journal of Sedimentary Research, v. 73, p. 603-620.

Grundvag, S.A., Johannessen, E.P., Helland-Hansen, W., and Plink-Björklund, P., 2014, Depositional architecture and evolution of progradationally stacked lobe complexes in the Eocene Central Basin of Spitsbergen: Sedimentology, v. 61, p. 535-569.

Hickson, T.A., and Lowe, D.R., 2002, Facies architecture of a submarine fan channellevee complex: the Juniper Ridge Conglomerate, Coalinga, California: Sedimentology, v. 49, p. 335-362.

Hiscott, R.N., Hall, F.R., and PiRmez, C., 1997, Turbidity current overspill from the Amazon Channel: texture of the silt/sand load, paleoflow from anisotropy of magnetic susceptibility and implications for flow processes, in Flood, R.D., Piper, D.J.W., Klaus, A., and Peterson, L.C., eds., Proceedings of the Ocean Drilling Program, Scientific Results, v. 155 , p. $53-78$.

Hodgson, D.M., Flint, S.S., Hodgetts, D., Drinkwater, N.J., Johannessen, E.P., and LutHI, S.M., 2006, Stratigraphic evolution of fine-grained submarine fan systems, Tanqua depocenter, Karoo Basin, South Africa: Journal of Sedimentary Research, v. 76 , p. $20-40$.

Hodgson, D.M., Di Celma, C.N., Brunt, R.L., and Flint, S.S., 2011, Submarine slope degradation and aggradation and the stratigraphic evolution of channel-levee systems: Geological Society of London, Journal, v. 168, p. 625-628.

Hubbard, S.M., and Shultz, M.R., 2008, Deep burrows in submarine fan-channe deposits of the Cerro Toro Formation (Cretaceous), Chilean Patagonia: implications for firmground development and colonization in the deep sea: Palaios, v. 23, p. $223-232$.

Hubbard, S.M., Romans, B.W., and Graham, S.A., 2008, Deep-water foreland basin deposits of the Cerro Toro Formation, Magallanes Magallanes basin, Chile: architectural elements of a sinuous basin axial channel belt: Sedimentology, v. 55, p. $1333-1359$.

Hubbard, S.M., de Ruig, M.J., and Graham, S.A., 2009, Confined channel-levee complex development in an elongate depo-center: deep-water Tertiary strata of the Austrian Molasse basin: Marine and Petroleum Geology, v. 26, p. 85-112.

Hubbard, S.M. Fildani, A., Romans, B.W. Covault, J.A., and McHargue, T.R., 2010, High-relief slope clinoform development: insights from outcrop, Magallanes Basin, Chile: Journal of Sedimentary Research, v. 80, p. 357-375.

Hubbard, S.M., MacEachern, J.A., and Bann, K.L., 2012, Slopes, in Knaust, K., and Bromley, R.G., eds., Trace Fossils and Indicators of Sedimentary Environments: Amsterdam, Elsevier, Developments in Sedimentology, v. 64, p. 607-642.

Hubbard, S.M., Covault, J.A., Fildani, A., and Romans, B.W., 2014, Sediment transfer and deposition in slope channels: deciphering the record of enigmatic deepsea processes from outcrop: Geological Society of America, Bulletin, v. 126, 857-871

HuBERT, J.F., 1966, Modification of the model for internal structures in graded beds to include a dune division: Nature, v. 211, p. 614-615.

Ito, M., Ishikawa, K., and Nishida, N., 2014, Distinctive erosional and depositional structures formed at a canyon mouth: a lower Pleistocene deep-water succession in the Kazusa forearc basin on the Boso Peninsula, Japan: Sedimentology, v. 61, p. 2042-2062.

Jackson, C.A.-L., Larsen, E., Hanslien, S., and Tuemsland, A.E., 2011, Controls on synrift turbidite deposition on the hanging wall of the South Viking Graben, North Sea rift system, offshore Norway: American Association of Petroleum Geologists, Bulletin, v. 95 , p. $1557-1587$.
Janocko, M., Nemec, W., Henriksen, S., and Warchol, M., 2013, The diversity of deep-water sinuous channel belts and slope valley-fill complexes: Marine and Petroleum Geology, v. 41, p. 7-34

Jobe, Z.R., Bernhardt, A., and Lowe, D.R., 2010, Facies and architectural asymmetry in a conglomerate-rich submarine channel fill, Cerro Toro Formation, Sierra de Toro, Magallanes Basin, Chile: Journal of Sedimentary Research, v. 80, p. 1085-1108. Kane, I.A., and Hodgson, D.M., 2011, Sedimentological criteria to differentiate submarine channel-levee subenvironments: exhumed examples from the Rosario Fm. (Upper Cretaceous) of Baja California, Mexico, and the Fort Brown Fm. (Permian), Karoo Basin, S. Africa: Marine and Petroleum Geology, v. 28, p. 807-823.

Kane, I.A., Kneller, B.C., Dykstra, M., Kassem, A., and McCaffrey, W.D., 2007, Anatomy of a submarine channel-levee: an example from Upper Cretaceous slope sediments, Rosario Formation, Baja California, Mexico: Marine and Petroleum Geology, v. 24, p. 540-563.

Kane, I.A., Dykstra, M.L., Kneller, B.C., Tremblay, S., and McCaffrey, W.D., 2009a Architecture of a coarse-grained channel-levee system: the Rosario Formation, Baja California, Mexico: Sedimentology, v. 56, p. 2207-2234.

Kane, I.A., McCaffrey, W.D., and Martinsen, O.J., 2009b, Allogenic vs. autogenic controls on megaflute formation: Journal of Sedimentary Research, v. 79, p. 643-651.

Kane, I.A., McCaffrey, B., Peakall, J., and Kneller, B., 2010, Submarine channellevee shape and sediment waves from physical experiments: Sedimentary Geology, v. 223 , p. $75-85$.

Kastens, K.A., and Shor, A.N., 1985, Depositional processes of a meandering channel on Mississippi Fan: American Association of Petroleum Geologists, Bulletin, v. 69, p. $190-202$.

Keith, B.D., and Friedman, G.M., 1977, A slope-fan-basin-plain model, Taconic Sequence, New York and Vermont: Journal of Sedimentary Petrology, v. 47, p. 1220 1241.

KNeller, B.C., and McCAFFrey, W.D., 2003, The interpretation of vertical sequences in turbidite beds: the influence of longitudinal flow structure: Journal of Sedimentary Research, v. 73, p. 706-713.

Kolla, V. Bandyopadhyay, A. Gupta, P Mukherjee, B and Ramana, V.D., 2012 Morphology and internal structure of a Recent upper Bengal fan-valley complex, in Prather, B.E., Deptuck, M.E., Mohrig, D., Van Hoorn, B., and Wynn, R.B., eds., Application of the Principles of Seismic Geomorphology to Continental-Slope and Base-of-Slope Systems: Case Studies from Seafloor and Near-Seafloor Analogues: SEPM, Special Publication 99, p. 347-369.

LEEDER, M.R., 1983, On the dynamics of sediment suspension by residual Reynolds stresses: confirmation of Bagnold Theory: Sedimentology, v. 30, p. 485-491.

Leeder, M.R., Gray, T.E., and Alexander, J., 2005, Sediment suspension dynamics and a new criterion for the maintenance of turbulent suspensions: Sedimentology, v. 52 , p. 683-691.

Levell, B.K., and Kasumajaya, A., 1985, Slumping at the late Miocene shelf-edge offshore West Sabah: a view of a turbidite basin margin: Geological Society of Malaysia, Bulletin, v. 18, p. 1-29.

Lowe, D.R., 1982, Sediment gravity flows 2. Depositional models with special reference to the deposits of high-density turbidity currents: Journal of Sedimentary Petrology, v 52, p. 279-298.

LuthI, S.M., and FLINT, S.S., 2014, The application of outcrop-based research boreholes for resevoir modelling: potential challanges and pitfalls, in Martinus, A.W., Howell, J.A., and Good, T., eds., Sediment-Body Geometry and Hetrogeneity: Analogue Studies for Modelling the Subsurface: Geological Society of London, Special Publications 387, p. 233-246.

Luthi, S.M., Hodgson, D.M., Geel, C.R., Flint, S.S., Goedbloed, J.W., Drinkwater, N.J., and Johannessen, E.P., 2006, Contribution of research borehole data to modelling fine-grained turbidite reservoir analogues, Permian Tanqua-Karoo basinfloor fans (South Africa): Petroleum Geoscience, v. 12, p. 175-190.

Macauley, R.V., and Hubbard, S.M., 2013, Slope channel sedimentary processes and stratigraphic stacking, Cretaceous Tres Pasos Formation slope system, Chilean Patagonia: Marine and Petroleum Geology, v. 41, p. 146-162.

MacDonald, H.A., Wynn, R.B., Huvenne, V.A.I., Peakall, J., Masson, D.G., Weaver, P.P.E., and McPhail, S.D., 2011, New insights into the morphology, fill, and remarkable longevity $(>0.2$ m.y.) of modern deep-water erosional scours along the northeast Atlantic margin: Geosphere, v. 7, p. 845-867.

Mayall, M., Jones, E., and CAsey, M., 2006, Turbidite channel reservoirs: key elements in facies prediction and effective development: Marine and Petroleum Geology, v. 23, p. $821-841$.

Meiburg, E., and Kneller, B., 2010, Turbidity currents and their deposits, Annual Review of Fluid Mechanics: Palo Alto, Annual Reviews, v. 42, p. 135-156.

Miller, K.G., Mountain, G.S., Browning, J.V., Katz, M.E., Monteverde, D., Sugarman, P.J., Ando, H. Bassetti, M.A., Buerrum, C. J., Hodgson, D., Hesselbo, S., Karakaya, S., Proust, J.-N., and Rabineau, M., 2013, Testing sequence stratigraphic models by drilling Miocene foresets on the New Jersey shallow shelf: Geosphere, v. 9, p. 1236-1256.

Morris, E.A., Hodgson, D.M., Brunt, R.L., and Flint, S.S., 2014, Origin, evolution and anatomy of silt-prone submarine external levees: Sedimentology, v. 61, p. 1734 1763.

Morris, S.A., Kenyon, N.H., Limonov, A.F., and Alexander, J., 1998, Downstream changes of large-scale bedforms in turbidites around the Valencia channel mouth, north-west Mediterranean: implications for palaeoflow reconstruction: Sedimentology, v. 45 , p. $365-377$ 
Moscardelli, L., Wood, L., and Mann, P., 2006, Mass-transport complexes and associated processes in the offshore area of Trinidad and Venezuela: American Association of Petroleum Geologists: Bulletin, v. 90, p. 1059-1088.

Mulder, T., and AleXander, J., 2001, The physical character of subaqueous sedimentary density flows and their deposits: Sedimentology, v. 48, p. 269-299.

MutTI, E., 1992, Turbidite Sandstones: San Donato, Milanese, Universitá di Parma, Agip, 275 p.

MutTi, E., and Normark, W.R., 1987, Comparing examples of modern and ancient turbidite systems: problems and concepts, in Leggett, J.K., and Zuffa, G.G., eds. Marine Clastic Sedimentology: Springer, The Netherlands, p. 1-38.

Nemec, W., Steel, R.J., Guelberg, J., Collinson, J.D., Prestholm, E., and Oxnevad, I.E., 1988, Anatomy of collapsed and re-established delta front in lower Cretaceous of eastern Spitsbergen: gravitational sliding and sedimentation processes: American Association of Petroleum Geologists, Bulletin, v. 72, p. 454-476.

Normark, W.R., 1978, Fan valleys, channels, and depositional lobes on modern submarine fans: characters for recognition of sandy turbidite environments: American Association of Petroleum Geologists, Bulletin, v. 62, p. 912-931.

Normark, W.R., Piper, D.J.W., and Hess, G.R., 1979, Distributary channels, sand lobes, and meso-topography of Navy Submarine Fan, California Borderland, with applications to ancient fan sediments: Sedimentology, v. 26, p. 749-774.

Normark, W.R., Piper, D.J.W. Posamentier, H. Pirmez, C., and Migeon, S., 2002, Variability in form and growth of sediment waves on turbidite channel levees: Marine Geology, v. 192, p. 23-58.

O'byrne, C., Prather, B.E., Pirmez, C., Barton, M., and Steffens, G.S., 2007, Coarsegrained bar forms in the Condor Channel Complex, Cerro Torro Formation at Lago Sarmiento, Chile, in Nilsen, T.H., Shew, R.D., Steffens, G.S., and Studlick, J., eds. Atlas of Deep-Water Outcrops: American Association of Petroleum Geologists, Studies in Geology 56, p. 154-156.

Olafiranye, K., Jackson, C.A.L., and Hodgson, D.M., 2013, The role of tectonics and mass-transport complex emplacement on upper slope stratigraphic evolution: a 3D seismic case study from offshore Angola: Marine and Petroleum Geology, v. 44, p. 196-216.

Ortiz-Karpf, A., Hodgson, D.M., and McCaffrey, W.D., 2015, The role of masstransport complexes in controlling channel avulsion and the subsequent sediment dispersal patterns on an active margin: the Magdalena Fan, offshore Colombia: Marine and Petroleum Geology, v. 64, p. 58-75.

Palanques, A., Kenyon, N.H., Alonso, B., and Limonov, A., 1995, Erosional and depositional patterns in the Valencia Channel mouth: an example of a modern channel-lobe transition zone: Marine Geophysical Researches, v. 17, p. 503-517.

Pantin, H.M., 1979, Interaction between velocity and effective density in turbidity flowphase-plane analysis, with criteria for autosuspension: Marine Geology, v. 31, p. 59-99.

Pantin, H.M., 2001, Experimental evidence for autosuspension, in McCaffrey, W. Kneller, B., and Peakall, J., eds., Particulate Gravity Currents: International Association of Sedimentologists, Special Publication 31, p. 189-205.

Pantin, H.M., and Franklin, M.C., 2009, Predicting autosuspension in steady turbidity flow: ignition points and their relation to Richardson Numbers: Journal of Sedimentary Research, v. 79, p. 862-871.

Pantin, H.M., and Franklin, M.C., 2011, Improved experimental evidence for autosuspension: Sedimentary Geology, v. 237, p. 46-54.

Paola, C., and Martin, J.M., 2012, Mass-balance effects in depositional systems: Journal of Sedimentary Research, v. 82, p. 435-450.

Parker, G., 1982, Conditions for the ignition of catastrophically erosive turbidity currents: Marine Geology, v. 46, p. 307-327.

Parker, G., Funushima, Y., and Pantin, H.M., 1986, Self-accelerating turbidity currents: Journal of Fluid Mechanics, v. 171, p. 145-181.

Paull, C.K., Mitts, P., Ussler, W., Keaten, R., and Greene, H.G., 2005, Trail of sand in upper Monterey Canyon: offshore California: Geological Society of America, Bulletin, v. 117, p. $1134-1145$.

Pickering, K.T., and Corregidor, J., 2005, Mass-transport complexes, (MTCs) and tectonic control on basin-floor submarine fans, middle Eocene, south Spanish Pyrenees: Journal of Sedimentary Research, v. 75, p. 761-783.

Pickering, K.T., Hodgson, D.M., Platzman, E., Clark, J.D., and Stephens, C., 2001, A new type of bedform produced by backfilling processes in a submarine channel, late Miocene, Tabernas-Sorbas basin, SE Spain: Journal of Sedimentary Research, v. 71, p. 692-704.

PIPER, D.J.W., and Normark, W.R., 1983, Turbidite depositional patterns and flow characteristics, Navy Submarine Fan, California Borderland: Sedimentology, v. 30, p. 681-694.

Piper, D.J.W., and Normark, W.R., 2001, Sandy fans: from Amazon to Hueneme and beyond: American Association of Petroleum Geologists, Bulletin, v. 85, p. 1407-1438.

PIPER, D.J.W., and SAVOYE, B., 1993, Processes of late Quaternary turbidity-current flow and deposition on the Var deep-sea fan, North-west Mediterranean Sea: Sedimentology, v. 40, p. 557-582.

Pirmez, C., and Flood, R.D., 1995, Morphology and structure of Amazon channel Proceedings of the Ocean Drilling Program, Initial Reports, v. 155, p. 23-45.

Posamentier, H.W., and Kolla, V., 2003, Seismic geomorphology and stratigraphy of depositional elements in deep-water settings: Journal of Sedimentary Research, v. 73, p. $367-388$

Postma, G., Nemec, W., and Kleinspenn, K.L., 1988, Large floating clasts in turbidites: a mechanism for their emplacement: Sedimentary Geology, v. 58, p. 47-61.

Prélat, A., Hodgson, D.M., and Flint, S.S., 2009, Evolution, architecture and hierarchy of distributary deep-water deposits: a high-resolution outcrop investigation from the Permian Karoo Basin, South Africa: Sedimentology, v. 56, p. 2132-2154.
Pyles, D.R., Jennette, D.C., Tomasso, M., Beaubouef, R.T., and Rossen, C., 2010, Concepts learned from a 3D outcrop of a sinuous slope channel complex: Beacon Channel Complex, Brushy Canyon Formation, West Texas, U.S.A: Journal of Sedimentary Research, v. 80, p. 67-96.

Romans, B.W., Hubbard, S.M., and Graham, S.A., 2009, Stratigraphic evolution of an outcropping continental slope system, Tres Pasos Formation at Cerro Divisadero, Chile: Sedimentology, v. 56, p. 737-764.

Rossen, C., and Beaubouef, R.T., 2008, Toe-of-slope channel complexes at Buena Vista, Upper Brushy Canyon Formation, Texas, USA, in Nilsen, T., Shew, R., Stefans, G., and Studlick, J., eds., Atlas of Deepwater Outcrops: American Association of Petroleum Geologists, Studies in Geology, v. 56, p. 450-456.

Rouse, H., 1937, Modern conceptions of the mechanics of fluid turbulence: American Society of Civil Engineers, Transactions, v. 102, p. 463-543.

Savoye, B., Cochonat, P., Apprioual, R., Bain, O., Baltzer, A., Bellec, V., Beuzart, P., Bourillet, J.-F., Cagna, R., Cremer, M., Crusson, A., Dennielou, B., Diebler, D., Droz, L., Ennes, J.-C., Floch, G., Guiomar, M., Harmegnies, F., Kerbrat, R., Kuien, B., Kuhn, H., Landure, J.-Y., Lasnier, C., Le Drezen, E., Le Formal, J.-P., Lopez, M., Loubrieu, B., Marsset, T., Migeon, S., Normand, A., Nouze, H., Ondreas, H., Pelleau, P., Saget, P., Seranne, M., Sibuet, J.-C., Tofani, R., and VoIsset, M., 2000, Structure and recent evolution of the Zaire deep-sea fan: preliminary results of the Zaiango 1 and 2 cruises (Angola-Congo Margin): Academie des Sciences Paris, Comptes Rendus, Serie II, Sciences de la Terre et des Planetes, v. 331 , p. $211-220$

Schwenk, T., Spieb, V., Hübscher, C., and Breitzke, M., 2003, Frequent channel avulsions within the active channel-levee system of the middle Bengal Fan: an exceptional channel-levee development derived from Parasound and Hydrosweep data: Deep Sea Research Part II: Topical Studies in Oceanography, v. 50, p. 1023 1045

Schwenk, T., Spieß, V., Breitzke, M., and Hübscher, C., 2005, The architecture and evolution of the Middle Bengal Fan in vicinity of the active channel-levee system imaged by high-resolution seismic data: Marine and Petroleum Geology, v. 22, p. 637-656.

SoHN, Y.K., 1997, On traction-carpet sedimentation: Journal of Sedimentary Research, v. 67 , p. $502-509$

SouthaRD, J.B., 1991, Experimental determination of bedform stability: Annual Review of Earth and Planetary Sciences, v. 19, p. 423-455.

Stevenson, C.J., Talling, P.J., Wynn, R.B., Masson, D.G., Hunt, J.E., Frenz, M. Akrmetzhanhov, A., and Cronin, B.T., 2013, The flows that left no trace: very largevolume turbidity currents that bypassed sediment through submarine channels without eroding the sea floor: Marine and Petroleum Geology, v. 41, p. 186-205.

Stevenson, C.J., Talling, P.J., Masson, D.G., Sumner, E.J., Frenz, M., and Wynn, R.B., 2014a, The spatial and temporal distribution of grain-size breaks in turbidites: Sedimentology, v. 61, p. 1120-1156.

Stevenson, C.J., Talling, P.J., Sumner, E.J., Masson, D.G., Frenz, M., and Wynn, R.B., 2014b, On how thin submarine flows transported large volumes of sand for hundreds of kilometres across a flat basin plain without eroding the sea floor: Sedimentology, v. 61, p. 1982-2019.

Stright, L., Stewart, J., Campion, K., and Graham, S., 2014, Geologic and seismic modeling of a coarse-grained deep-water channel reservoir analog (Black's Beach, La Jolla, California): American Association of Petroleum Geologists, Bulletin, v. 98, p. $695-728$

Strong, N., and Paola, C., 2008, Valleys that never were: time surfaces versus stratigraphic surfaces: Journal of Sedimentary Research, v. 78, p. 579-593.

Sullivan, M.D., Jensen, G.N., Goulding, F., Jenette, D.C., Foreman, J.L., and STERN, D., 2000, Architectural analysis of deep-water outcrops: implications for exploration and development of the Diana sub-basin: SEPM, Gulf Coast Section, 20th Annual Research Conference, Deep-Water Reservoirs of the World Location: Western Gulf of Mexico, p. 1010-1031

Sumner, E.J., Talling, P.J., Amy, L.A., Wynn, R.B., Stevenson, C.J., and Frenz, M., 2012, Facies architecture of individual basin-plain turbidites: comparison with existing models and implications for flow processes: Sedimentology, v. 59, p. 1850-1887.

Sylvester, Z., and Lowe, D.R., 2004, Textural trends in turbidites and slurry beds from the Oligocene flysch of the East Carpathians, Romania: Sedimentology, v. 51, p. $945-972$.

Sylvester, Z., Pirmez, C., and Cantelli, A., 2011, A model of submarine channel-levee evolution based on channel trajectories: implications for stratigraphic architecture: Marine and Petroleum Geology, v. 28, p. 716-727.

Talling, P.J., Wynn, R.B., Masson, D.G., Frenz, M., Cronin, B.T., Schiebel, R., Akhmetzhanov, A.M., Dallmeier-Tiessen, S., Benetti, S., Weaver, P.P.E., Georgiopoulou, A., Zuhlsdorff, C., and Amy, L.A., 2007, Onset of submarine debris flow deposition far from original giant landslide: Nature, v. 450, p. $541-544$.

Talling, P.J., Masson, D.G., Sumner, E.J., and Malgesini, G., 2012, Subaqueous sediment density flows: depositional processes and deposit types: Sedimentology, v. 59, p. 1937-2003.

Talling, P.J., Allin, J., Armitage, D.A., Arnott, R.W.C., Cartigny, M.J.B., Clare, M.A., Felletti, F., Covault, J.A., Girardclos, S., Hansen, E., Hill, P.R., Hiscott, R.N., Hogg, A.J., Clarke, J.H., Jobe, Z.R., Malgesini, G., Mozzato, A., Naruse, H., Parkinson, S., Peel, F.J., Piper, D.J.W., Pope, E., Postma, G., Rowley, P., Sguazzini, A., Stevenson, C.J., Sumner, E.J., Sylvester, Z., Watts, C., and Xu, J.P., 2015, Key future directions for research on turbidity currents and their deposits: Journal of Sedimentary Research, v. 85, p. 153-169. 
Thomas, D.W., and Coward, M.P., 1996, Mesozoic regional tectonics and South Viking Graben formation: evidence for localized thin-skinned detachments during rift development and inversion: Marine and Petroleum Geology, v. 13, p. 149-177.

Twichell, D.C., Kenyon, N.H., Parson, L., and McGrego, B.A., 1991, Depositional patterns of the Mississippi Fan surface: evidence from GLORIA II and highresolution seismic profiles, in Weimer, P., and Link, M.H., eds., Seismic Facies and Sedimentary Processes of Submarine Fans and Turbidite Systems: New York, Springer, p. 349-363.

Twichell, D.C., Schwab, W.C., Nelson, C.H., Kenyon, N.H., and Lee, H.J., 1992, Characteristics of a sandy depositional lobe on the outer Mississippi Fan from SEAMARC IA side-scan sonar images: Geology, v. 20, p. 689-692.

VAN Risn, L., 1984, Sediment transport, Part II: suspended load transport: Journal of Hydraulic Engineering, v. 110, p. 1613-1641.

VAN RIJN, L.C., 1993, Principles of sediment transport in rivers, estuaries and coastal seas: Amsterdam, Aqua Publications, 690 p.

van der Merwe, W.C., Hodgson, D.M., Brunt, R.L., and Flint, S.S., 2014 Depositional architecture of sand-attached and sand-detached channel-lobe transition zones on an exhumed stepped slope mapped over a $2500 \mathrm{~km}^{2}$ area: Geosphere, v. 10, p. $1076-1093$

van Maren, D.S., Winterwerp, J.C., Wang, Z.Y., and Pu, Q., 2009, Suspended sediment dynamics and morphodynamics in the Yellow River, China: Sedimentology, v. 56, p. $785-806$

van Wagoner, J.C., Mitchum, R.M., Campion, K.M., and Rahmanian, V.D., 1990, Siliciclastic sequence stratigraphy in well logs, cores, and outcrops: American Association of Petroleum Geologists, Methods in Exploration, Special Publication 7, p. $3-55$.

WidEss, M.B., 1973, How thin is a thin bed: Geophysics, v. 38, p. 1176-1180.
WinN, R.D., and Dotr, R.H., 1977, Large-scale traction structures in deep-water fan-channel conglomerates in southern Chile: Geology, v. 5, p. 41-44.

WinN, R.D., and DotT, R.H., 1979, Deep-water fan-channel conglomerates of Late Cretaceous age, southern Chile: Sedimentology, v. 26, p. 203-228.

Wynn, R.B., Kenyon, N.H., Masson, D.G., Stow, D.A.V., and Weaver, P.P.E., 2002a, Characterization and recognition of deep-water channel-lobe transition zones: American Association of Petroleum Geologists, Bulletin, v. 86, p. 1441-1462.

Wynn, R.B., Weaver, P.P.E., Masson, D.G., and Stow, D.A.V., 2002b, Turbidite depositional architecture across three interconnected deep-water basins on the northwest African margin: Sedimentology, v. 49, p. 669-695.

Wynn, R.B., Cronin, B.T., and Peakall, J., 2007, Sinuous deep-water channels: genesis, geometry and architecture: Marine and Petroleum Geology, v. 24, p. 341-387. Wynn, R.B., Talling, P.J., Masson, D.G., Stevenson, C.J., Cronin, B.T., and Le BAS, T.P., 2010, Investigating the timing, processes and deposits of one of the world's largest submarine gravity flows: The "Bed 5 Event" off Northwest Africa, in Mosher, D.C., Shipp, R.C., Moscardelli, L., Chaytor, J.D., Baxter, C.D.P., Lee, H.J., and Urgeles, R., eds., Submarine Mass Movements and Their Consequences: Advances in Natural and Technological Hazards Research: Dordrecht, Springer, p. $463-474$.

Wynn, R.B., Talling, P.J., Masson, D.G., Le Bas, T.P., Cronin, B.T., and Stevenson, C.J., 2012, The influence of subtle gradient changes on deep-water gravity flows: a case study from the Moroccan Turbidite system, in Prather, B.E., Deptuck, M.E. Mohrig, D., Van Hoorn, B., and Wynn, R.B., eds., Application of the Principles of Seismic Geomorphology to Continental-Slope and Base-of-Slope Systems: Case Studies from Seafloor and Near Seafloor Analogues: SEPM, Special Publication 99, p. $371-383$.

Received 3 September 2014; accepted 28 May 2015. 